\title{
Sekizinci Sınıf Öğrencilerinin Fen Bilimleri Dersinde Akıllı Tahta Kullanımına Yönelik Tutumlarının İncelenmesi
}

\author{
Investigation of Eighth Grade Students' Attitudes Towards Smartboard Use in Science \\ Class*
}

\section{Hasan GÖKÇE ${ }^{1}$, Oktay BEKTAŞ ${ }^{2}$, Fulya ÖNER ARMAĞAN ${ }^{3}$}

1Doktora öğrencisi, Erciyes Üniversitesi, hasangokce3838@gmail.com, (iD 0000-0002-1518-2295

${ }^{2}$ Doç. Dr., Erciyes Üniversitesi, obektas@erciyes.edu.tr, (iD)0000-0002-2562-2864

${ }^{3}$ Doç. Dr., Erciyes Üniversitesi, fulyaner@yahoo.com, (iD 0000-0003-2085-1390

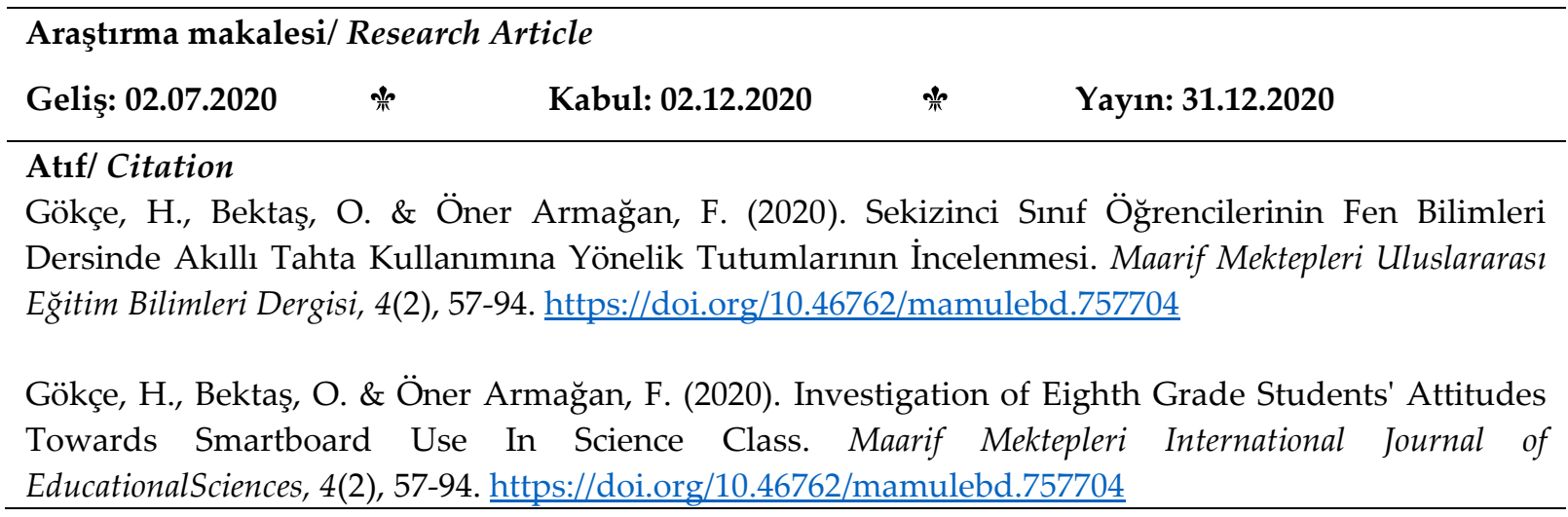

Öz

Bu araştırmada, Kayseri İli Melikgazi ilçesindeki üç farklı ortaokulda öğrenim gören sekizinci sınıf öğrencilerinin, fen bilimleri dersinde kullanılan akıllı tahtaya yönelik tutumları tespit edilerek bunun cinsiyet, yıllara göre akıllı tahta deneyimi ve bilgisayar kullanım tecrübesi değişkenlerine göre farklılık gösterip göstermediğinin incelenmesi amaçlanmaktadır. Nicel araştırma yönteminin kullanıldığ tercih edilmiştir. Tarama deseninden, kesitsel tarama deseni türü seçilmiştir. Araştırma 20172018 öğretim yılının güz yarıyılında yapılmıştır. Araştırmanın ulaşılabilir evreni, Kayseri İli Melikgazi İlçesinde eğitim-öğretim faaliyetlerinde akıllı tahtayı aktif olarak kullanan ortaokul sekizinci sınıf öğrencileridir. Araştırmanın örneklemi, Kayseri İli Melikgazi

*Bu makale 29-31 Mart 2018 tarihinde Ankara'da yapılan 6. Uluslararası Çin'den Adriyatik'e Sosyal Bilimler Kongresinde Sözlü Bildiri olarak sunulmuştur. 
İlçesinde eğitim-öğretim faaliyetlerinde akıllı tahtayı aktif olarak üç yıldır kullanan bir devlet ortaokulunun, iki yıldır kullanan bir devlet ortaokulunun, bir yıldır kullanan bir devlet ortaokulunu sekizinci sınıf öğrencileri oluşturmaktadır. "Akıllı tahta kullanımına yönelik tutum ölçeği" veri toplama aracı olarak kullanılmıştır. Araştırma sonuçlarına göre sekizinci sınıf öğrencilerinin fen bilimleri dersinde akıllı tahta kullanımına yönelik tutumlarının genel olarak olumlu olduğu görülmüştür. Ayrıca öğrencilerin fen bilimleri dersinde akıllı tahta kullanımına yönelik tutumlarının cinsiyete, yıllara göre akıllı tahta deneyimine ve bilgisayar kullanım tecrübesine göre farklılık göstermediği sonucuna ulaşılmıştır. İleride yapılacak araştırmaların; farklı derslerde, farklı öğrenim seviyelerinde yapılması ayrıca veri toplama araçlarından ölçeğe ek olarak mülakatlarla desteklenmesi önerilmektedir.

Anahtar Kelimeler: Akıllı tahta, Fatih projesi, tutum, fen bilimleri, nicel araştırma

\section{Abstract}

In this research, it is aimed to investigate whether the eighth-grade students in the city of Kayseril Melikgazi district have different attitudes towards the smartboard used in science lessons and whether they differ according to gender, in respect to years of smartboard experience and computer use experience. The research in which quantitive method is applied, survey design is used. From the survey, the cross-sectional survey scan pattern type is selected. The research is conducted during the fall semester of the 2017-2018 academic year. The accessible universe of the study is the eighth-grade students who are actively using the smartboard in educational activities in the city of Kayseri/Melikgazi District. The sample of the study consists of a state secondary school which has been actively using smartboard for three years, a state secondary school which has been using it for two years and a state secondary school which has been using it for one year in its educational activities in the city of Kayseri/Melikgazi District in eighth grade students. Developed by Arslan (2014), attitude scale for smartboards was used as data collection tool. According to the results of the research, it is seen that eighth-grade students' attitudes towards smartboards use in science class generally are positive. In addition, students' attitudes towards smartboards use in science class did not differ according to variables such as gender, years of smartboards experience and level of computer use experience. It suggested that future studies should be conducted at different learning levels in different class as well as interviews in addition to data collection tolls such as scale.

Keywords: Smartboard, Fatih project, attitude, science, quantitative research

\section{Giriş}

Günümüz yaşam şartlarındaki değişiklikler, bilgi ve teknolojinin hızla gelişmesi insanları hayatlarındaki tüm alanlarda değişikliklere ve yeniliklere yönlendirmiştir (Tataroğlu, 2009). Çağımızda teknoloji akıl almaz bir hızla gelişmektedir (Pamuk, Çakır, Ergun, Yılmaz ve Ayas, 2013; Tekin, 2013). Bu gelişen teknolojiye insanların ayak uydurması zorunludur (Hiçyılmaz, 2015). Her alanda etkili olan bu değişimler eğitim alanını da etkilemektedir (Tataroğlu, 2009; Tekin, 2013).

Teknolojide meydana gelen değişimler eğitim ortamının da sürekli olarak değişmesine neden olmuştur. Teknolojideki gelişmelerle birlikte eğitimdeki araç ve gereçlerin de yenilenmesi gerekmekte aksi takdirde çağın ihtiyaçlarını karşılaması mümkün olmamaktadır. Dolayısıyla eğitim öğretimde çağın getirdiği teknolojik imkânlar kullanılmadır (Solak, 2012). 
Dünyada teknolojinin ilerleme kaydetmesiyle, eğitim öğretimde de arayışlar devam etmiş ve böylece, uygulanan öğretim programlarında değişiklikler yapılmıştır (Tekin, 2013). Eğitim alanında hedeflerimize ulaşmak için, çağın ihtiyaçlarına cevap verecek gelişen teknolojiyi eğitim alanına uyarlanması ve kullanılmasıyla mümkün görülmektedir (Seyitoğlu, 2014). Çağımızın getirdiği teknoloji Internet, multimedya, animasyon, film gibi yollarla eğitime uyarlanmaktadır (Pekdağ, 2005). Günümüz teknolojisinin eğitime uyarlandığı, Türkiye' de ve tüm dünyada ilgi gören araçlardan birisi de akıllı tahtalardır. Akıllı tahtalar, eğitimde istendik hedeflere ulaşmamızı sağlayan önemli araçlardandır. Eğitim-öğretimde akıllı tahtaların kullanılmaya başlanması ile birlikte Milli Eğitim Bakanlığı FATïH projesini başlatmış ve bu projeyle birçok sınıf akıllı tahtaya sahip olmuştur (Seyitoğlu, 2014).

Kısaca FATİH olarak adlandırılan, Fırsatları Artırma ve Teknolojiyi İyileştirme Hareketi isimli proje Milli Eğitim Bakanlığı ile Ulaştırma, Denizcilik ve Haberleşme Bakanlığı'nın işbirliğinde yürütülen ve 2010 Kasım ayında kamuoyuna duyurulan bir projedir (Tekin, 2013). Öncelikle projeyle ilgili pilot uygulamalar gerçekleşmiş olup asıl uygulama 2013-2014 eğitim-öğretim yılında hayata geçirilmiştir (Seyitoğlu, 2014). FATïH projesinin amacı, Türkiye'de zaman ve mekândan bağımsız olarak öğrencilerin sosyo-ekonomik durumları ayırt etmeksizin çağın teknolojisinden yararlanmasını sağlamak ve öğrencilere eğitim-öğretim faaliyetlerinde fırsat eşitliğini sağlamaktır. FATİH projesi, Türkiye'de bulunan okullara teknolojiyi entegre ederek eğitim-öğretimin zirveye çıkması adına, okulöncesi, ilkokul, ortaokul ve lise düzeyinde akıllı tahta alt yapısının oluşturulması amaçlamıştır (Milli Eğitim Bakanlığ $[\mathrm{MEB}]$, 2012).

Akıllı tahta, Amerika, İngiltere, Kanada ve Japonya gibi birçok ülkede uzun zamandır kullanılan, Türkiye'de de ismini son beş yıllık süreçte duyduğumuz bir eğitim-öğretim aracıdır (Tekin, 2013). Akıllı tahtalar, yabancı alanyazında "interactive whiteboard, smartboard, electronic board" olarak karşımıza çıkmaktayken Türkiye'de de "etkileşimli tahta, akıllı tahta" olarak adlandırılmaktadır (Saruhan, 2015). Günümüzde akıllı tahtalar, eğitim-öğretim araçları içerisinde en popülerleri arasında sayılmaktadır (Emrem, 2014). Çoklu ortam özelliklerine sahip olan akıllı tahtalar, öğrencilerin bilişsel, duyuşsal ve zihinsel gelişimlerine katkı sağlayacak eğitim öğretim faaliyetlerinin gerçekleşmesi için en uygun teknolojik araçlardan birisi olduğu söylenmektedir (Saruhan, 2015). Türkiye'de ise akıllı tahtalar FATİH projesi ile sınıf ortamına entegre edilmiş olup bilgisayarlı dokunmatik ekran, geleneksel yazı tahtası ve beyaz tahta gibi bileşenlerden oluşmaktadır (Bağcl, 2013; Yalçınkaya, 2013).

Ülkeler bilim ve teknoloji alanında adeta birbirleriyle yarışmaktadırlar. Bu yarışta ön saflarda yer alabilmek için fen bilimlerine büyük önem vermektedirler (MEB, 2006). Fen bilimleri eğitimi hem ülkeler hem de bireyler için bu denli önemliyken bireylerin fen bilimlerine karşı olumlu tutum geliştirmesi fikri ortaya çıkmıştır. Bu fikirle birlikte öğrencilerde fen bilimlerine karşı olumlu tutum geliştirilmesinde fen bilimleri dersinin doğru ve etkili bir biçimde sunulması göz ardı 
edilemez (Doğru ve Aydoğdu, 2003). Çünkü öğrenciye doğru ve etkili bir biçimde sunulan fen bilimleri dersi gelecekte fen eğitimine yön verecek tutumların oluşmasına zemin hazırlar. Günümüz teknolojisinin getirisi olan akıllı tahtaları fen bilimleri dersine etkili ve doğru bir biçimde entegre etmeliyiz ki öğrencilerin tutumlarında olumlu yönde etki gerçekleştirsin.

Tutum, belirli nesnelere, durumlara, kurumlara, kavramlar veya insanlara karşı olumlu veya olumsuz bir şekilde tepki verme eğilimidir (Gagne, Briggs ve Wager, 1992). Bu ifadeyle birlikte bireyin sergilediği her davranışın altında sahip olduğu tutumlar etkilidir diyebiliriz. Yani tutumlar bireyin davranışını biçimlendiren unsurlardır (İnceoğlu, 2010). Herhangi bir derse karşı geliştirilen tutumlar olumlu ise öğrenme rahat ve kolay gerçekleşir. Aksine tutumlar olumsuz ise öğrenmeyi engelleyici niteliktedir (Turgut ve Baykul, 2015). Derse yönelik tutumların önceden bilinmesiyle öğrencilerde tutum değişikliği sağlanabilir (Furat, 2009).

Bireydeki tutumların kaynağı, herhangi bir olay, nesne veya birey ile ilgili geçmiş yaşantılarının sonucu veya çevresinden yapmış olduğu gözlemler sonucu oluşmaktadır (İnceoğlu, 2010). Bu durumun fen bilimleri dersi için de geçerli olduğunu söyleyebiliriz. Yani öğrencinin fen bilimleri dersine, konularına, materyallerine karşı edinmiş olduğu tutumlar zaman içinde eğitim öğretim faaliyetlerinin öğrencide bıraktığı izlenimler sonucu meydana gelmektedir. Öğrencinin fen bilimleri dersini sevip sevmemesi edindiği bu izlenim ve deneyimlerin sonucu belirlenir. Erken yaşlarda öğrencilerin fen bilimleri dersine karşı edinecekler tutumlar ileriki yaşamlarında bilimsel bakış açısını da etkileyecektir (Külçe, 2005).

Öğrencilerin fen bilimlerine karşı geliştirdikleri tutumu sadece okuldaki fen ve doğadaki fen arasında bağlantı kurup kurmamaları ile sınırlı değildir. Bu tutumun gelişmesinin altında birçok faktör vardır. Bunlar arasında eğitim altyapısı, okul ortamı, öğretmen, aile, arkadaş, öğrencinin motivasyonu, geçmiş başarıları, kendine güveni, fene karşı ilgisi gibi faktörler öne çıkmaktadır (Külçe 2005). Yine bu faktörler arasından sayılabilecek olan fen bilimleri dersinde kullanılan eğitim-öğretim araçları da fen bilimleri tutumu geliştirilmesinde önemli yere sahiptir (Fuat, 2009). Bu tutumu değiştirebilecek etkiye sahip eğitim-öğretim araçlarından birisinin de akıllı tahtalar olduğu düşünülmektedir.

\section{Araştırmanın Amacı ve Önemi}

Yıllardır eğitimin temel yapıtaşları olarak öğretmen, ders kitabı ve tahta karşımıza çıkmaktaydı. Bilim ve teknoloji alanındaki gelişmelerle birlikte günümüz teknolojisi gündelik hayatta her alanda etkisini gösterdiği gibi eğitim alanında da etkisini göstermiş ve geleneksel öğretim yöntem ve teknikleri farklılaşmaya başlamıştır (Tekin, 2013).

Kaliteli bir eğitim öğretim faaliyeti gerçekleştirmek istiyorsak kullanacağımız yöntem-teknik, araç-gereç ve materyaller oldukça önemlidir. Öğrencilerin kalıcı 
bilgilerine bakılacak olursa duyduklarından çok gördüğü ve yaparak yaşayarak edindiği bilgilerdir (Yalçınkaya, 2013). Yani bir öğrenme faaliyeti olabildiğince duyuya hitap ettiği sürece öğrencilerde o denli kalıcı izli bilgiler olmaktadır (Aktaş, 2015). Günümüz bilgi ve teknolojik gelişmeleri sonucunda ortaya çıkan akıllı tahtalar, zaman ve mekândan bağımsız bir şekilde dünyanın herhangi bir yerini ders ortamına getirilmesi ile günümüz teknolojisinde önemli bir yere sahiptir (Türkoğlu, 2014).

Akıllı tahtaların kullanılmasıyla eğitim öğretim faaliyetlerindeki faydaları ve getirileri gün geçtikçe artmaktayken (Kaya, 2013), Türkiye'de eğitimde giderek yaygınlaşan akıllı tahtalardan gerektiği ölçüde faydalanmak istemektedir (Tataroğlu, 2009). Günümüz eğitim alanına da yakın zamanda giren eğitim öğretim araçlarının başında gelen akıllı tahtalar ile ilgili araştırmalar yapılarak bilim penceresinden konuya bakılması akıllı tahtalar ile ilgili daha olumlu etkiler yaratacaktır (Dikmen, 2015).

Türkiye'de akıllı tahtalar eğitim-öğretimde kullanılmaya yakın zamanda başladığı için, bu yöndeki alanyazın sınırlı sayıdadır (Aktaş, 2015; Saruhan, 2015; Tekin, 2013). Türkiye'de büyük yatırımlarla eğitim-öğretim ortamına dâhil edilen akıllı tahtaların, eğitim-öğretimde ne şekilde etkili ve verimli kullanılacağının bilinmesi bu yatırımları daha anlamlı hale getirecektir (Tekin, 2013). Bu bakımdan öğrenme ortamına entegre edilen akıllı tahtaların verimli bir şekilde nasıl kullanılabileceğinin araştırılması kaçınılmazdır. Bu sebepten alanyazında sınırlı çalışmanın olması ve mevcut akıllı tahtaların ne şekilde etkili kullanılabileceğine cevap aranması bu araştırmanın yapılmasının başlıca nedenleri arasındadır.

Türkiye'de ve yurt dışında akıllı tahtanın eğitim-öğretim kullanımına ilişkin araştırmalar yapılmıştır. $\mathrm{Bu}$ araştırmalar akıllı tahtanın eğitim-öğretimde kullanımına ilişkin olup genel olarak orta öğretim (Eke, 2014; Emrem, 2014; Sarıkaya, 2015; Önder, 2015; Özçelik, 2015; Ünal, 2015) ve üniversite düzeyinde öğretmen adaylarına (Tekinarslan vd., 2015; Yorgancı ve Terzioğlu, 2013) yönelik olduğu görülmektedir. Ancak ortaokul düzeyinde çalışmalara bakıldı̆̆ında (Damcott, Landato ve Marsh, 2000; Dereli, 2016; Kırbağ-Zengin, Kırılmazkaya ve Keçeci, 2011; Tiryaki, 2014; Türkoğlu, 2014) diğerlerine nazaran sinırlı sayıda olduğu görülmektedir.

Akıllı tahtalar ile ilgili yapılan çalışmalar branş dersleri yönünden değerlendirilecek olursak hemen hemen bütün branşlara yönelik çalı̧̧malar mevcuttur. Örneğin fen bilimleri dersi (Aktaş, 2015; Ermiş, 2012; Kırbağ-Zengin vd., 2011; Öztan, 2012; Sakız, Özden, Aksu ve Şimşek, 2014; Tercan, 2012; Tiryaki, 2014;Türkoğlu, 2014), matematik dersi (Akgün ve Koru-Yücekaya, 2015; Clemens, Moore ve Nelson, 2003; Glover, Miller ve Averis, 2005; Oleksiw, 2007; Robinson, 2004; Yorgancı ve Terzioğlu, 2013; Winkler, 2011), sosyal bilgiler dersi (Kaya ve Aydın, 2011); biyoloji dersi (Sarıkaya, 2015; Önder, 2015), fizik dersi (Emrem, 2014; 
Özçelik, 2015), tarih dersi (Ünal, 2015), İngilizce dersi (Eke, 2014; Toscu, 2013), müzik dersi (Saruhan,2015), görsel sanatlar dersi (Hiçyılmaz, 2015).

Akıllı tahtalar ile ilgili yapılan çalışmalar öğretmenlere (Akgün ve KoruYücekaya, 2015; Baydaş, Esgice, Kalafat ve Göktaş, 2011; Bulut ve Koçoğlu, 2012; Bell, 2002; Erduran ve Tataroğlu, 2009; Hiçyılmaz, 2015; Saruhan, 2015; Smith, 2000) ve öğrencilere (Aytaç, 2013; Beeland, 2002; Isman, Abanmy, Hussein, Saadany ve Abdelrahman, 2012; Min ve Siegel, 2011;Smith, Higgins, Wall ve Miller, 2005; Sünkür vd., 2012; Türel ve Johnson, 2012; Wall, Higgins ve Smith, 2005; Weimer, 2001) yönelik yapılmıştır.

Akıllı tahtalar ile ilgili yapılan çalışmalarda araştırmacılar, genellikle tutumlar (Akgün ve Koru-Yücekaya, 2015; Aytaç, 2013; Bağcl, 2013; Beeland, 2002; Clemens vd., 2003; Glover vd., 2005; Günbatar ve Gökçearslan, 2017; Isman vd., 2012; Min ve Siegel, 2011; Oleksiw, 2007; Önder, 2015; Robinson, 2004; Smith vd., 2005; Sünkür vd., 2012; Türel ve Johnson, 2012; Wall vd., 2005;Weimer, 2001), motivasyonlar (Eke, 2014; Kaya ve Aydın,2011; Saruhan, 2015; Tekinarslan vd., 2015; Yorgancı ve Terzioğlu, 2013), başarı (Aktaş, 2015; Emrem, 2014; Ermiş, 2012; Kırbağ-Zengin vd., 2011; Öztan, 2012; Sarıkaya, 2015; Özçelik, 2015; Sakız vd., 2014; Tercan, 2012; Tiryaki, 2014; Türkoğlu, 2014;Yorgancı ve Terzioğlu, 2013), kalıcılık (Aktaş, 2015; Kırbağ-Zengin vd., 2011) düzeylerindeki farklılıklar ve akıllı tahta ölçeği geliştirme (Arslan, 2014; Çelik ve Atak, 2012) üzerine yoğunlaşmışlardır.

Akıllı tahtanın fen bilimleri dersinde kullanımına yönelik çalışmalar mevcuttur. Bu çalışmalar da genellikle tutum (Damcott vd., 2000; Dereli, 2016; Kırbağ-Zengin vd., 2011; Ermiş, 2012; Öztan, 2012; Sakız vd., 2014; Tercan, 2012; Tiryaki, 2014; Türkoğlu, 2014), başarı (Aktaş, 2015; Ermiş, 2012; Kırbağ-Zengin vd., 2011; Öztan, 2012; Sakız vd. 2014; Tercan, 2012; Tiryaki, 2014; Türkoğlu, 2014), kalıcllı (Aktaş, 2015; Kırbağ-Zengin vd., 2011) değişkenleri üzerinde yoğunlaşmıştır.

FATİH projesinin asıl merkezi olan öğrencilerin fen bilimleri dersinde akıllı tahta kullanımına yönelik tutumlarını inceleyen, öğrencilere yeni olan bu teknolojinin fen bilimleri eğitimine entegre edilmesinde öğrencilerin fikirlerini belirleyen araştırmaların sayısının artması gerektiği düşünülmektedir. Tutum gibi duyuşsal özellikler, eğitim-öğretim faaliyetlerinde teknolojinin etkili bir biçimde kullanılmasında önemli role sahiptir. Akıllı tahtaların derslerde ne derece etkili olduğunun belirlenmesi için kullanılan bu teknolojinin olumlu ve olumsuz yönlerinin belirlenmesi ve bu sebeple akıllı tahtaların öğrenme ortamına entegre edilmesiyle beklendik yararın sağlanması için öğrenci tutumlarının bilinmesi gereklidir. Akıllı tahtalardan istenilen başarıyı yakalamak için öğrenmeyi etkileyen faktörlerden en önemlisi olduğu düşünülen tutumların tespit edilmesiyle; istendik yönde tutum değişikliği oluşturulabileceği, eğitim-öğretim ortamı öğrencinin durumuna göre yeniden tasarlanabileceği, öğrenciye tutum değişikliği konusunda gerekli yönlendirmeler yapılabileceği düşünülmektedir. 
Fen bilimleri dersinde akıllı tahtanın kullanımına yönelik öğrenci tutumları açısından yapılan çalışmalarda cinsiyet değişkeninin (Damcott vd., 2000; Ermiş, 2012; Kırbağ-Zengin vd., 2011; Sakız vd., 2014; Türkoğlu, 2014) ele alındığı çalışmalar oldukça sınırlıdır. Ayrıca alanyazında fen bilimleri dersinde öğrencilerin akıllı tahta kullanımın öğrencilerin yıllara göre deneyimi açısından incelenen herhangi bir çalışmaya rastlanmamıştır. Bu bağlamda araştırmamızla birlikte aynı sınıf seviyesinde ancak akıllı tahta ile farklı yıllarda deneyime sahip öğrencilerin tutumlarına ilişkin fikir sahibi olunması açısından gelecekteki uygulamalara ışık tutacağı düşünülmektedir. Akıllı tahtaların farklı değişkenler (cinsiyet, bilgisayar kullanma tecrübesi, akıllı tahta kullanım deneyimi) açısından incelenmesi öğrencilerin tutumlarının daha net bir ortaya koyacağı düşünülmektedir.

Araştırmamızda FATİH projenin asıl merkezi olan öğrencilere, akıllı tahtalar ile ilgili söz hakkı tanınarak, fikirleri alınmış ve fen bilimleri dersinde kullanılan akıllı tahtalara ilişkin tutumları belirlenmeye çalışılmıştır. Öğrencilerin akıllı tahtaya yönelik tutumlarının bilinmesi, eğitimcilere eğitim-öğretim faaliyetlerini düzenlerken bu durumu göz önünde bulundurmalarına imkân sağlayacaktır. Bu noktadan hareketle araştırmanın amacı, Kayseri İli Melikgazi ilçesindeki üç farklı ortaokulda öğrenime devam eden sekizinci sınıf öğrencilerinin fen bilimleri dersinde kullanılan akıllı tahtaya yönelik tutumları tespit edilerek bunun cinsiyet, yıllara göre akıllı tahta deneyimi ve bilgisayar kullanım tecrübesi gibi değişkenlere göre farklılık gösterip göstermediğinin incelenmesidir.

\section{Araştırmanın Problem Cümlesi}

$\mathrm{Bu}$ araştırmanın problem cümlesi, "Kayseri İli Melikgazi İlçesinde öğrenim gören sekizinci sınıf öğrencilerinin fen bilimleri dersinde akıllı tahta kullanımına yönelik tutumları ne düzeydedir?" şeklindedir.

\section{Araştırmanın Alt Problemleri}

1. Sekizinci sınıf öğrencilerinin fen bilimleri dersinde akıllı tahta kullanımına yönelik tutumları, cinsiyete göre değişmekte midir?

2. Sekizinci sınıf öğrencilerinin fen bilimleri dersinde akıllı tahta kullanımına yönelik tutumları, yıllara göre akıllı tahta kullanım deneyimine (1 yıl, 2 yıl, 3 yll) göre değişmekte midir?

3. Sekizinci sınıf öğrencilerinin fen bilimleri dersinde akıllı tahta kullanımına yönelik tutumları, bilgisayar kullanım tecrübesine $(0-2,3-4,5-6,7-8,9$ ve üzeri) göre değişmekte midir?

\section{Araştırma Hipotezleri}

Araştırmanın bu kısmında her bir probleme ilişkin 0.05 anlamlılık düzeyinde aşağıdaki sıfır hipotezleri (null hipotezleri) kurulmuştur. Sıfır hipotezi, araştırma hipotezinde belirlenen parametrik değer ile gerçek değer arasında "fark yoktur" 
prensibine dayanır (Kalaycı, 2017). Bu araştırmadaki sıfır hipotezler aşağıda verilmiştir.

$H_{1}$ : Sekizinci sınıf öğrencilerinin fen bilimleri dersinde akıllı tahta kullanımına yönelik tutumları ile cinsiyetleri arasında anlamlı bir fark yoktur.

$H_{2}$ : Sekizinci sınıf öğrencilerinin fen bilimleri dersinde akıllı tahta kullanımına yönelik tutumları ile yıllara göre akıllı tahta kullanım deneyimi (1 yıl, 2 yıl, 3 yil) arasında anlamlı bir fark yoktur.

$H_{3}$ : Sekizinci sınıf öğrencilerinin fen bilimleri dersinde akıllı tahta kullanımına yönelik tutumları ile bilgisayar kullanım tecrübesi $(0-2,3-4,5-6,7-8,9$ ve üzeri) arasında anlamlı bir fark yoktur.

\section{Yöntem}

\section{Araştırma Deseni}

$\mathrm{Bu}$ araştırmada nicel araştırma yöntemi kullanılmış olup tarama deseni tercih edilmiştir. Bir konu veya olayla ilgili olarak katılımcıların görüşlerinin belirlendiği veya tutum, beceri, ilgi gibi özelliklerinin belirlendiği ve genel olarak büyük örneklemlerle yapılan araştırmalara tarama araştırmaları denir (Büyüköztürk, Kılıç Çakmak, Akgün, Karadeniz ve Demirel, 2016). Bu desenin seçilme nedeni, örneklemdeki öğrencilere ilişkin tutumların olduğu gibi betimlenmesi ve elde edilen bu verilerle ilişkilerin çözümlemelerinin yapılacak olmasıdır. Bu durumu karşılayacak desen tarama desenidir. Tarama deseninden, kesitsel tarama deseni türü seçilmiştir. Fraenkel ve Wallen (2008) kesitsel tarama desenini, önceden belirlenen bir topluluğun herhangi bir zamanda bir konuya ilişkin görüşlerinin veya özelliklerinin betimlenmesi şeklinde tanımlamaktadırlar. Önceden planlanmadan herhangi bir zamanda örneklemin tutumları betimlendiği için kesitsel desen türü tercih edilmiştir.

\section{Evren - Örneklem}

$\mathrm{Bu}$ araştırmanın ulaşılabilir evreni Kayseri İli Melikgazi İlçesinde eğitimöğretim faaliyetlerinde akıllı tahtayı aktif olarak kullanan ortaokul sekizinci sınıf öğrencileridir. Ulaşılabilir evrenden örneklem seçilirken Nunnally, örneklemdeki sayısının madde sayısının 10 katı; Gorusch, 15 katı; Tavşancıl ise 5-10 katı olması gerektiğini ifade etmiştir (akt. Yiğit, Bütüner ve Dertlioğlu, 2008). Yapılan araştırmada 36 maddelik akıllı tahta tutum ölçeği için verimli netice alınması istemiyle örneklem sayısı 438 kişi olarak belirlenmiştir.

$\mathrm{Bu}$ araştırma örneklemini, Kayseri İli Melikgazi İlçesinde eğitim-öğretim faaliyetlerinde akıllı tahtayı aktif olarak üç yıldır kullanan bir devlet ortaokulunun, iki yıldır kullanan bir devlet ortaokulunun, bir yıldır kullanan bir devlet ortaokulunu sekizinci sınıf öğrencileri oluşturmaktadır. Bu araştırmada seçkisiz olmayan örnekleme türü tercih edilmiştir. Seçkisiz olmayan örnekleme türü, örnekleme 
alınacak birimlerin seçkisizlik ilkesine bağlı olmaksızın belirlenmesine denir. Bu araştırmada amaçsal örnekleme deseni kullanılmıştır. Bunu sebebi ise amaçsal örnekleme, seçkisiz olmayan bir örnekleme deseni olmasıdır. Belirli ölçütlere ve niteliklere sahip özel durumlarda çalışmak istenildiği takdirde kullanılır.

Yapılan araştırmada, sekizinci sınıf öğrencilerinin seçilmesinin nedeni olarak Türkiye' de ortaokullarda kısa geçmişi olan akıllı tahtaların ortaokul seviyelerinde en fazla kullanma tecrübesine sahip olabilecek öğrencilerin sekizinci sinıf düzeyinde olabileceği varsayımını dayanmaktadır. Tablo 1'de araştırmaya katılan sekizinci sınıf öğrencilerine ait cinsiyet, okul türü ve bilgisayar kullanma tecrübelerine ilişkin frekans ve yüzde değerleri yer almaktadır.

Tablo 1.Öğrencilerin cinsiyet, okul türü ve bilgisayar kullanma tecrübelerine ilişkin dağıllımı

\begin{tabular}{lccc}
\hline Demografik özellikler & & $\mathrm{f}$ & $\%$ \\
\hline \multirow{2}{*}{ Cinsiyet } & Kiz & 220 & 50,2 \\
& Erkek & 218 & 49,8 \\
Okul türü & A (3 y1l) & 163 & 37,2 \\
& B (2 yıl) & 178 & 40,6 \\
& C (1 yıl) & 97 & 22,1 \\
Bilgisayar Kullanma & $0-2$ yıl & 95 & 21,7 \\
Tecrübesi & $3-4$ yıl & 83 & 18,9 \\
& $5-6$ yıl & 107 & 24,4 \\
& $7-8$ yıl & 102 & 23,3 \\
Toplam & 9 ve üzeri yıl & 51 & 11,6 \\
\hline
\end{tabular}

Araştırmaya katılan 438 öğrenciden 220'si kız (\%50.2) ve 218'i erkek (\%49.8); 163 öğrenci A okulundan, 178 öğrenci B, 97 öğrenci C okulundan katılmaktadır. Ayrıca bilgisayar kullanma tecrübeleri 0-2 yıl 95 öğrenci, 3-4 yıl 83 öğrenci, 5-6 yıl 107 öğrenci, 7-8 yıl 102 öğrenci 9 ve üzeri yıllarda 51 öğrenci mevcuttur.

\section{Veri Toplama Araçları}

Veri toplama aracı olarak kullanılan akıllı tahta kullanımına yönelik tutum ölçeği" ne ilişkin bilgiler aşağıda bulunmaktadır.

\section{Akıllı tahta kullanımına yönelik tutum ölçeği}

Araştırmada Arslan (2014) tarafından geliştirilen "akıllı tahta kullanımına yönelik tutum ölçeği" kullanılmıştır. Geliştirilen ölçek 36 maddeden oluşmaktadır. Ölçeğe ilişkin geçerlik ve güvenirlik çalışmaları aşağıda verilmiştir.

\section{Geçerliğe ilişkin bulgular}

Geçerlik kavramı, belli amaçlarla oluşturulan maddelerin hedeflenen özellikleri veya soruları gerçekten ölçüp ölçmediğinin derecesi yani maddelerin ölçmenin amacına hizmet etme derecesi olarak tanımlanmaktadır (Seçer, 2015; Turgut ve Baykul, 2015). Bu bölümde “fen bilimleri dersinde kullanılan akıllı tahtaya yönelik 
tutum ölçeği" için ise kapsam, ölçüt ve yap1 geçerliğine ilişkin bulgular bulunmaktadir.

\section{Kapsam geçerliği}

Bir ölçme aracının ölçülmek istenilen davranışları ölçmede yeterli olup olmadığının göstergesi kapsam geçerliği olarak tanımlanmaktadır (Büyüköztürk, 2011). Ölçeğin kapsam geçerliğini sağlamak amacıyla uzman görüşleri ve bazı ek istatistiksel işlemler gerçekleştirilmiştir.

\section{Uzman görüş̧leri}

Arslan (2014) tarafından geliştirilen “akıllı tahta kullanımına yönelik tutum ölçeği"ndeki maddelerinin değerlendirilmesi amacıyla fen eğitiminde bir uzmandan, iki fen bilimleri öğretmeninden ve iki Türkçe öğretmeninden görüş alınmıştır. 36 maddeden oluşan ölçek için uzman ve öğretmenlerle yüz yüze görüşmeler yapılmıştır. Maddelerin uygunluğunu değerlendirmek için uzman ve fen bilimleri öğretmenleri ile şu konulara dikkat edilmiştir:

- $\quad$ Bu maddeler fen bilimleri derslerinde kullanılan akıllı tahtaya karşı tutumu ölçmekte midir?

- Bu maddeler ortaokul öğrencilerin seviyesine uygun ifade edilmiş midir?

- Bu ölçeğe eklemek istedikleriniz veya önerileriniz nelerdir?

Fen eğitimi uzmanının görüşleri doğrultusunda 36 maddelik tutum ölçeği incelenmiş ve "akıllı tahta kullanımına yönelik" ifadesi "fen bilimleri dersinde kullanılan akıllı tahtaya yönelik" olarak değiştirilmiştir. Ayrıca uzman ve öğretmenlerin görüşleri doğrultusunda, maddelerin fen bilimleri derslerinde kullanılan akıllı tahtaya karşı tutumu ölçmek için uygunluğuna ve öğrenci seviyesine uygunluğuna karar verilmiştir. Maddelerin uygunluğunu değerlendirmek için Türkçe öğretmenleri ile şu konulara dikkat edilmiştir:

- Bu maddeler ortaokul öğrencilerin anlayabileceği seviyede midir?

- Bu maddelerde yazım ve anlam bozukluğu yönünden hatalar var mıdır?

Türkçe öğretmenlerinin görüşleri doğrultusunda 36 maddelik tutum ölçeği incelenmiştir ve öğrencilerin seviyesine uygun olduğu belirtilmiştir. Ayrıca bazı maddelerdeki anlam bozukluğu içeren ifadeler düzeltilmiştir. Örneğin, “...sınıf kalabalık olsa da rahat ders işlenebilir." ifadesi "...sınıf kalabalık olsa da ders rahat işlenebilir." şeklinde değişiklikler yapılmıştır.

\section{Ek istatistiksel işlemler}

Ölçeğin kapsam geçerliğini incelemek üzere, bazı ek istatistiksel işlemler gerçekleştirilmiştir. Öncelikle tutum ölçeği puanlarından 1, 2 olarak girilen puanlar 0 olarak kodlanmış, 3 olarak girilen puanlar analize dâhil edilmemiş, 4, 5 olarak girilen puanlar 1 olarak kodlanmıştır. Buradan hareketle, öğrencilerin tutum ölçeğinden 
aldıkları puanlar yüksekten düşüğe doğru sıralanmış ve ilk \%27'lik ve son \%27'lik gruplar belirlenmiştir. Toplam üst grubu belirlerken 438 öğrenci arasından puanı en yüksek olan \%27'lik öğrencilerin puanlarına alınmıştır. Bu öğrencilerden 115. sıradaki öğrencinin aldığ1 puanın 27 olduğu tespit edilmiştir. Ancak 27 puan alan 14 öğrencinin daha olduğu tespit edilmesi üzerine üst grubun öğrenci sayısı 129 olarak alınmıştır. Toplam alt grubu belirlerken 438 öğrenci arasından puanı en düşük olan \%27'lik öğrencilerin puanlarına alınmıştır. Bu öğrencilerden sondan 115. sıradaki öğrencinin aldığı puanın 15 olarak tespit edilmiştir. Daha da yukarıda 15 puan alan öğrenci olmadığı için alt grubun öğrenci sayısı 115 olarak alınmıştır. \%27'lik alt grup ve \%27'lik üst gruplara göre madde ayırt edicilik indeksleri (r) ve madde güçlük indeksleri ( $p$ ) hesaplanmıştır. Ölçeğe ilişkin $r, p$ değerleri Tablo 4 'te verilmiştir. Her bir maddeye ilişkin madde güçlük indeksi ve madde ayırt edicilik indeksleri hesaplanmıştır. Hesaplamalarda aşağıdaki formüller kullanılmıştır (Turgut ve Baykul, 2015).

$$
p_{j}=\frac{n_{(d, \ddot{\mathrm{u}})}+n_{(d, a)}}{2 N^{\prime}}, r_{j x}=\frac{n_{(d, \mathrm{ü})}-n_{(d, a)}}{N^{\prime}}
$$

pj: Madde güçlük indeksi

rjx: Madde ayırıcılık gücü indeksi

$\mathrm{n}(\mathrm{d}, \mathrm{u})$ : Maddeyi üst grupta doğru yanıtlayanların sayısı

$\mathrm{n}(\mathrm{d}, \mathrm{a})$ : Maddeyi alt grupta doğru yanıtlayanların sayısı

$\mathrm{N}^{\prime}$ : Üst ya da alt gruptaki öğrenci sayısı

Madde ayırt edicilik indeksi, bir maddeyi bilenle bilmeyen öğrenciyi ayırt etme derecesidir. Madde ayırt edicilik indeksleri hesaplanan maddelerin değerlendirilmesinde (Ebel ve Frisbie, 1991) tarafindan belirlenen tablo 2'deki ölçütler dikkate alınmıştır.

Tablo 2. Ayırt edicilik indekslerine göre değerlendirme ölçütleri

\begin{tabular}{ll}
\hline Ayırt Edicilik İndeks Değeri & \multicolumn{1}{c}{ Değerlendirme } \\
\hline 0.19 veya daha küçük & Kesinlikle ölçeğe alınmamalı veya tamamen düzeltilmelidir. \\
$0.20-0.29$ arası & Düzeltilerek ölçeğe alınabilir. \\
$0.30-0.39$ arası & Düzeltme yapmaksızın ölçeğe alınabilir. \\
0.40 veya daha yüksek & Çok iyi işleyen maddedir, ölçeğe olduğu gibi alınabilir. \\
\hline
\end{tabular}

Madde güçlük indeksi, her bir madde ilişkin doğru cevaplanma yüzdesini verir. Güçlük indeksi 0- 1 arası değer almaktadır. Bu değerin 1'e yaklaşması kolay, 0'a yaklaşması zor, 0.50 civarı olması ise orta güçlükte bir madde olduğunu gösterir. (Atılgan, 2016; Turgut ve Baykul, 2015).

Madde güçlük indeksleri hesaplanan maddelerin değerlendirilmesinde tablo 3'teki gibi aralıklara kullanabiliriz. 
Tablo 3. Madde güçlük indekslerine göre madde seçme ölçütleri

\begin{tabular}{ll}
\hline Güçlük İndeksi Değeri (r) & Değerlendirme \\
\hline 0.61 veya daha büyük & Kolay \\
$0.60-0.40$ arası & Orta \\
0.39 veya daha küçük & Zor \\
\hline
\end{tabular}

Tablo 4. Tutum ölçeğinin madde ayırt edilicilik ve güçlük indeksleri

\begin{tabular}{|c|c|c|c|c|}
\hline $\begin{array}{l}\text { Madde } \\
\text { No }\end{array}$ & $\mathrm{r}$ & $\mathrm{p}$ & Ayırt Edicilik İndeksi (r) Yorumları & $\begin{array}{c}\text { Güçlük İndeksi (p) } \\
\text { Yorumları }\end{array}$ \\
\hline 1 & .68 & .71 & Çok iyi işleyen (Yüksek) & Kolay \\
\hline 2 & .58 & .65 & Çok iyi işleyen (Yüksek) & Kolay \\
\hline 3 & .37 & .36 & Çok iyi işleyen (Yüksek) & Zor \\
\hline 4 & .74 & .68 & Çok iyi işleyen (Yüksek) & Kolay \\
\hline 5 & .77 & .60 & Çok iyi işleyen (Yüksek) & Orta \\
\hline 6 & .62 & .55 & Çok iyi işleyen (Yüksek) & Orta \\
\hline 7 & .74 & .68 & Çok iyi işleyen (Yüksek) & Kolay \\
\hline 8 & .83 & .64 & Çok iyi işleyen (Yüksek) & Kolay \\
\hline 9 & .90 & .59 & Çok iyi işleyen (Yüksek) & Orta \\
\hline 10 & .76 & .64 & Çok iyi işleyen (Yüksek) & Kolay \\
\hline 11 & .67 & .64 & Çok iyi işleyen (Yüksek) & Kolay \\
\hline 12 & .48 & .48 & Çok iyi işleyen (Yüksek) & Orta \\
\hline 13 & .59 & .60 & Çok iyi işleyen (Yüksek) & Orta \\
\hline 14 & .69 & .68 & Çok iyi işleyen (Yüksek) & Kolay \\
\hline 15 & .66 & .46 & Çok iyi işleyen (Yüksek) & Orta \\
\hline 16 & .78 & .64 & Çok iyi işleyen (Yüksek) & Kolay \\
\hline 17 & .57 & .75 & Çok iyi işleyen (Yüksek) & Kolay \\
\hline 18 & .69 & .69 & Çok iyi işleyen (Yüksek) & Kolay \\
\hline 19 & .72 & .64 & Çok iyi işleyen (Yüksek) & Kolay \\
\hline 20 & .64 & .61 & Çok iyi işleyen (Yüksek) & Kolay \\
\hline 21 & .46 & .41 & Çok iyi işleyen (Yüksek) & Orta \\
\hline 22 & .41 & .50 & Çok iyi işleyen (Yüksek) & Orta \\
\hline 23 & .77 & .52 & Çok iyi işleyen (Yüksek) & Orta \\
\hline 24 & .80 & .63 & Çok iyi işleyen (Yüksek) & Kolay \\
\hline 25 & .76 & .61 & Çok iyi işleyen (Yüksek) & Kolay \\
\hline 26 & .70 & .64 & Çok iyi işleyen (Yüksek) & Kolay \\
\hline 27 & .54 & .57 & Çok iyi işleyen (Yüksek) & Orta \\
\hline 28 & .56 & .56 & Çok iyi işleyen (Yüksek) & Orta \\
\hline 29 & .63 & .55 & Çok iyi işleyen (Yüksek) & Orta \\
\hline 30 & .77 & .65 & Çok iyi işleyen (Yüksek) & Kolay \\
\hline 31 & .67 & .66 & Çok iyi işleyen (Yüksek) & Kolay \\
\hline 32 & .59 & .57 & Çok iyi işleyen (Yüksek) & Orta \\
\hline 33 & .77 & .64 & Çok iyi işleyen (Yüksek) & Kolay \\
\hline 34 & .78 & .52 & Çok iyi işleyen (Yüksek) & Orta \\
\hline 35 & .05 & .38 & Kesinlikle ölçeğe alınmamalı & Zor \\
\hline 36 & -.16 & .21 & Kesinlikle ölçeğe alınmamalı & Zor \\
\hline
\end{tabular}

Tablo 4'te görüldüğü gibi, maddelerin $r$ değerlerinin 0.19 veya daha küçük iki madde, 0.30-0.39 arası bir madde, 0.40 veya daha yüksek 34 madde bulunurken 0.20- 
0.29 arası değere sahip madde bulunmamıştır. Ölçekteki 35. ve 36. maddelerin ayırt edicilik indeksleri 0.19 'un altında olduğu için iki madde ölçekten çıkartılması gerektiğine karar verilmiştir. Ancak diğer maddeler incelendiğinde $\mathrm{r}$ değerlerinin $0.40^{\prime} \tan$ büyük olduğu görülmektedir (madde 3 hariç). Buna göre ölçekteki maddelerin ayırt edicilik düzeylerinin iyi olduğu söylenebilir. Ayrıca tablo 2'deki madde güçlük indeksleri incelendiğinde 0.61 veya daha büyük değere sahip 20 madde, 0.60-0.40 arası değere sahip 13 madde ve 0.39 veya daha küçük değere sahip üç madde bulunmaktadır. Bu açıklamalardan yola çıkarak ölçekte kolay, orta ve zor maddeler bulunduğu ancak çoğunun kolay madde olduğu görülmektedir.

Uygulanan ölçek için ortalama güçlük $(p)=0.59$ ve ortalama ayırt edicilik indeksi $(r)=0.67$ hesaplanmıştır. Ölçekte yer alan maddelerin güçlük dereceleri $(p)=$ $0.36-0.71$ aralığındayken ayırt edicilik indeksleri ise $(r)=0.37-0.90$ aralığındadır.

\section{Yapı geçerliği}

Bir ölçekte, ölçülmek istenen davranışın soyut bir kavramı (faktörü) doğru olarak ölçme derecesidir (Büyüköztürk, 2011). Arslan (2014) tarafından akıllı tahta kullanımına yönelik tutumlarını ölçmek amacıyla geliştirilen ölçekte, altı faktöre dengeli biçimde dağılım gösteren 36 madde bulunmaktadır. Bu faktörler sırasıyla şöyledir; faktör 1: akıllı tahtanın motive etme düzeyi, faktör 2: akıllı tahtanın zihinsel alana olumsuz etki düzeyi, faktör 3: akıllı tahtanın görselliğe etki düzeyi, faktör 4: akıllı tahtanın fiziksel hareket alana etkisi, faktör 5: akıllı tahtanın bireysel öğrenme düzeyine etkisi, faktör 6: akıllı tahtanın ders tekrarı üzerine etki düzeyi.

Arslan (2014) tarafından geliştirilen ölçeğin alt boyutlarına ait Cronbach $\alpha$ değerleri .533 ile .905 arasında değer almaktadır. Cronbach $\alpha$ değerlerifaktör 1 için.905, faktör 2 için .856, faktör 3 için 0.852, faktör 4 için 0.739 , faktör 5 için .757 ve faktör 6 için .533 olarak hesaplanmıştır. Ölçekte yer alan 36 maddenin Cronbach $\alpha$ değerini ise .940 olduğu hesaplanmıştır.

Ölçeğin faktör yapısının incelenmesi sürecinde, doğrulayıcı faktör analizi (DFA) ve açımlayıcı faktör analizi (AFA) kullanılmıştır. DFA ve AFA ölçeğin yapı geçerliliğinin değerlendirilmesi ilişkin bilgiler sağlayacaktır. AFA ölçeğin boyutları hakkında bilgi verirken, DFA ise bu boyutları belirli olan doğruluğunu ölçek etmek için kullanılır (Büyüköztürk, 2011).

Bir ölçme aracının geliştirilmesi sürecinde AFA'ya başlayabilmenin iki önemli şartı bulunmaktadır. Bu şartlar Kaiser-Meyer-Olkin (KMO) değeri ve Barlett's testinden elde edilen sonuçlardır. KMO testi, örneklem büyüklüğü hakkında bilgi verir. Bu bilgi ise örneklem büyüklüğünün yeterli olup olmadığına ilişkindir. Bu değerin en az 0.7 ve üzerini ölçüt almamız gerektiği belirtilmektedir. Barlett's testi sonuçları ise verilerin normal dağılımdan gelip gelmediğini belirtmektedir. Bu testin sonuçlarına ilişkin değerin anlamlı olması gerekir (Seçer, 2015).

Tutum ölçeğine ait Kaiser-Meyer-Olkin (KMO) değeri ve Barlett's testi sonuçları tablo 5 'te verilmiştir. 
Tablo 5.Ölçeğe ait Kaiser-Meyer-Olkin (KMO) değeri ve Barlett's testi sonuçları

\begin{tabular}{lcr}
\hline Kaiser-Meyer-Olkin & Örneklem İçin Uygunluk Ölçüsü & .925 \\
Bartlett'in Küresellik Testi & Yakşalık Ki Kare Değeri & 5878.617 \\
& Df & 561 \\
& p. & .000 \\
\hline
\end{tabular}

Tablo 5'teki değerler incelendiğinde, araştırmada kullanılan 34 maddelik ölçeğe ilişkin 438 kişilik örneklem büyüklüğünün yeterli olduğu ifade edilebilir. Ayrıca ölçeğin KMO değeri 0.925 olarak, Bartlett's testi değeri .000 bulunması sonucunda anlamlı olduğu $(p<.05)$ bulunmuştur. KMO ve Bartlett's testi sonuçlardan yola çıkılarak, örneklem büyüklüğünün ve verilerin normal dağılımının faktör analizine devam etmek için uygun olduğu yönünde karar verilmiştir.

Ölçeğin faktör analizine uygunluğuna karar verildikten sonra varimax döndürme yöntemi kullanılarak AFA uygulanmıştır. Yapılan analizlerde ölçeğin faktör sayısının belirlenmesi için, her bir faktöre ait olan öz değerin " 1 " in üzerinde olması gerekir. Ayrıca ölçeğin açıklaması gereken toplam varyans değerinin de bir kritik değeri vardır. Ancak ölçeğin açıklaması gereken varyans oranına ilişkin farklı görüşler bulunmaktadır. Pituch ve Stevens, açılanan varyansın en az \%75 ve üzeri olması gerektiği belirtmekteyken (Pituch ve Stevens, 2016), Henson ve Roberts ise yaptıkları araştırmada bir ölçme aracının açıkladığı varyans oranının \%52 ve üzeri olması gerektiği belirtmektedir (Henson ve Roberts, 2006). Ölçeğe ilişkin toplam varyans değerleri tablo 6' da verilmiştir.

Tablo 6.Tutum ölçeğinin toplam varyans değerleri

\begin{tabular}{cccc}
\hline Faktör & Öz değer & Varyansin Yüzdesi & Toplam Yüzde \\
\hline 1 & 9.932 & 29.211 & 29.211 \\
2 & 3.147 & 9.255 & 38.466 \\
3 & 1.690 & 4.972 & 43.438 \\
4 & 1.463 & 4.302 & 47.740 \\
5 & 1.120 & 3.294 & 51.034 \\
6 & 1.054 & 3.101 & 54.135 \\
\hline 7 & .962 & 2.830 & 56.965 \\
8 & .911 & 2.680 & 59.645 \\
9 & .880 & 2.587 & 62.232 \\
10 & .835 & 2.457 & 64.689 \\
11 & .800 & 2.352 & 67.041 \\
12 & .794 & 2.337 & 69.377 \\
13 & .761 & 2.239 & 71.617 \\
14 & .672 & 1.976 & 73.593 \\
15 & .631 & 1.855 & 75.447 \\
16 & .626 & 1.840 & 77.287 \\
17 & .611 & 1.796 & 79.083 \\
18 & .563 & 1.656 & 80.740 \\
19 & .551 & 1.621 & 82.360 \\
20 & .528 & 1.552 & 83.913
\end{tabular}




\begin{tabular}{llcl}
21 & .527 & 1.550 & 85.463 \\
22 & .517 & 1.521 & 86.984 \\
23 & .484 & 1.422 & 88.406 \\
24 & .468 & 1.378 & 89.784 \\
25 & .446 & 1.313 & 91.097 \\
26 & .430 & 1.266 & 92.363 \\
27 & .406 & 1.195 & 93.558 \\
28 & .375 & 1.103 & 94.662 \\
29 & .361 & 1.061 & 95.722 \\
30 & .339 & .996 & 96.718 \\
31 & .317 & .933 & 97.651 \\
32 & .297 & .872 & 98.523 \\
33 & .274 & .807 & 99.330 \\
34 & .228 & .670 & 100.000 \\
\hline
\end{tabular}

Tablo 6'da öz değeri 1'den büyük altı faktör bulunmaktadır. Birinci faktör toplam varyansın \%29.211'ini açıklamaktadır. Birinci ve ikinci faktör toplam varyansın \%38.466'sını açıklamaktadır. Tabloya bu şekilde bakıldığında, altı faktör toplam varyansın \%54.135'ini açıklamaktadır. Bu rakam da orta seviyede kabul edilebilir derecedir. Çünkü bu tutum ölçeğinin açıkladığı varyans oranının, açıklanamayan varyans oranından yüksek olması görülmektedir (\%54.135). Ayrıca maddelerin ortak faktör varyansının .324- .663 arasında olduğu belirlenmiştir.

Sadece toplam varyansa bakılarak ölçeğin kaç faktörden oluştuğuna karar verilemez. "Scree Plot" grafiği de ölçeğin kaç faktörünün olduğunun bilgisini verir. Şekil 1'de ölçeğin “Scree Plot" grafiği verilmiştir.

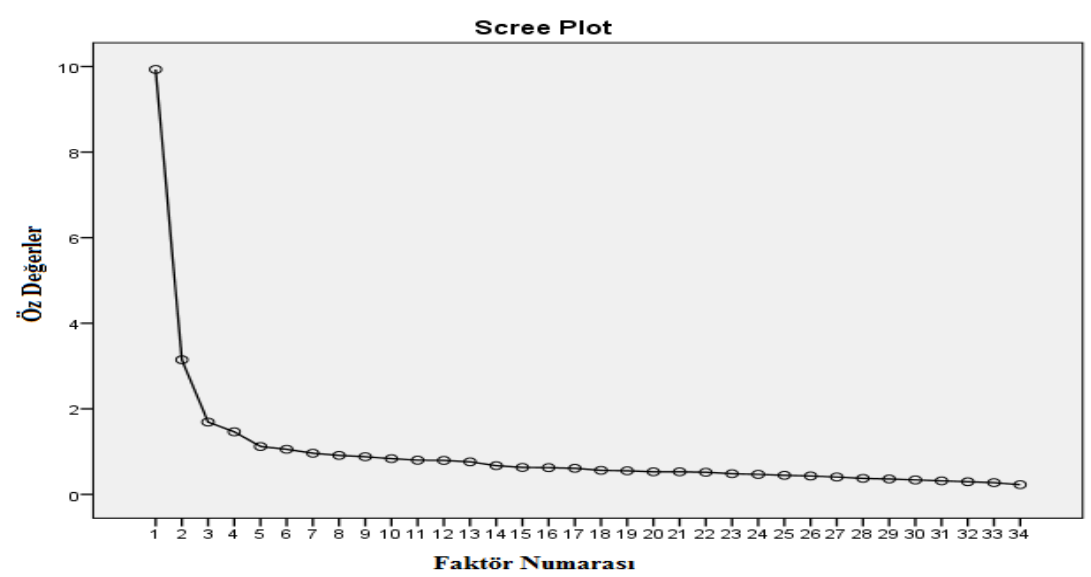

Şekil 1.Ölçek faktör analizine ilişkin Scree Plot grafiği

Şekil 1 incelendiğinde eğimin altınc faktörden sonra düzleştiği görülmektedir. Dolayısıyla ölçeğin anlamlı olarak altı faktörden oluştuğu ifade edilebilir.

Ölçeğe ilişkin faktör sayısının belirlenmesinin ardından faktörlere ait olan maddelerin hangilerinin olduğunu ve maddelere ilişkin faktör yüklerinin belirlenmesi gerekir. Herhangi bir ölçme aracındaki maddelerin hangi faktöre ait olduğunu tespit etmek için maddeye ilişkin faktör yüklerini incelemek gerekir. Madde faktör yükü değerinin en az 0.32 olması gerektiği ifade edilebilir (Seçer, 2015). 
$\mathrm{Bu}$ araştırmada, tutum ölçeği için madde faktör yük değeri sınırı 0.32 olarak alınmıştır. Maddelerin madde faktör yükleri ve faktörlere dağılımı Tablo 7'da verilmiştir.

Tablo 7. Ölçeğin faktör analizi sonrası dönüştürülmüş bileşenler matriksi

\begin{tabular}{|c|c|c|c|c|c|c|c|}
\hline \multirow[b]{2}{*}{ Maddeler } & \multicolumn{6}{|c|}{ Faktörler } & \multirow{2}{*}{$\begin{array}{c}\text { Ortak } \\
\text { Faktör } \\
\text { Varyans }\end{array}$} \\
\hline & Faktör 1 & Faktör 2 & Faktör 3 & Faktör 4 & Faktör 5 & Faktör 6 & \\
\hline Madde1 & .723 & & & & & & .646 \\
\hline madde8 & .719 & & & & & & .611 \\
\hline madde4 & .719 & & & & & & .669 \\
\hline madde2 & .705 & & & & & & .578 \\
\hline madde9 & .692 & & & & & & .623 \\
\hline madde5 & .690 & & & & & & .569 \\
\hline madde7 & .687 & & & & & & .599 \\
\hline madde10 & .516 & & & & & & .458 \\
\hline madde24 & .493 & .344 & & & & & .480 \\
\hline madde13 & .361 & & & & & & .324 \\
\hline madde32 & & .745 & & & & & .604 \\
\hline madde33 & & .732 & & & & & .627 \\
\hline madde31 & .381 & .664 & & & & & .593 \\
\hline madde 30 & & .658 & & & & & .528 \\
\hline madde34 & & .637 & & & & & .544 \\
\hline madde26 & .440 & .453 & & & & & .447 \\
\hline madde25 & & .425 & & .383 & & & .428 \\
\hline madde12 & & & .643 & & & & .499 \\
\hline madde11 & & & .618 & & & & .517 \\
\hline madde16 & & & .597 & & & & .493 \\
\hline madde14 & & & .582 & .355 & & & .558 \\
\hline madde6 & .340 & & .544 & & & & .497 \\
\hline madde17 & & & & .751 & & & .663 \\
\hline madde18 & & & .329 & .688 & & & .628 \\
\hline madde20 & & & & .630 & .328 & & .569 \\
\hline madde19 & .419 & & & .443 & & & .494 \\
\hline madde28 & & & & & .765 & & .604 \\
\hline madde29 & & & & & .684 & & .603 \\
\hline madde27 & & & & & .650 & & .525 \\
\hline madde22 & & & & & .353 & -.349 & .376 \\
\hline madde21 & & & & & & .719 & .569 \\
\hline madde3 & & & & & & .514 & .444 \\
\hline madde15 & .383 & & & & & .502 & .472 \\
\hline madde 23 & .411 & & & & & .453 & .568 \\
\hline
\end{tabular}

Tablo 7 incelendiğinde, ölçeğin altı faktör olduğu görülmektedir. Birinci faktörde 10 madde, ikinci faktörde 7 madde, üçüncü faktörde 5 madde, dördüncü faktörde 4 madde, beşinci faktörde 4 madde, altıncı faktörde 5 madde olduğu görülmektedir. Altı faktör olarak belirlenen maddelerin faktör yük değerleri 0.3280.765 arasında değişmektedir. Ölçeğe ilişkin ortak varyans değerleri ve faktör yükleri tablo 9' da verilmiştir. Tablodaki faktör yük değerlerine bakıldığında bazı 
maddelerin $(19,22,23,24,25,26)$ iki faktörde de bulunabilecek düzeyde faktör yük değeri olduğu görülmektedir. Yani binişiktir. Bu maddeler iç tutarlığı olumsuz etkilememesi nedeniyle ölçekte kalması uygun görülmüştür. Bu maddelerden yüksek olan değerdeki faktör altına alınmıştır.

Ölçekte yer alan madde içeriklerine bakıldığında, altı faktör altında belirlenen maddelerin birbiriyle uyum içinde olduğu görülmektedir. $\mathrm{Bu}$ durumda da faktörlerdeki maddelerin içeriklerine göre faktör isimlendirilmesi yapılmasına imkân tanımaktadır. Böylelikle her bir faktör tablo 8'deki gibi isimlendirilmiştir.

Tablo 8. Faktör analizi sonucunda belirlenen alt boyutlar ve bu boyutlardaki maddeler

\begin{tabular}{lcl}
\hline Faktör İsimlendirmesi & Faktör Madde Sayısı & Faktör Altındaki Maddeler \\
\hline Motive Düzeyi & 10 & $1,2,4,5,7,8,9,10,13,24$ \\
Görsellik Düzeyi & 7 & $25,26,30,31,32,33,34$ \\
Bilişsel Düzey & 5 & $6,11,12,14,16$ \\
Öğrenme Algı Düzeyi & 4 & $17,18,19,20$ \\
Fiziksel Hareket Düzeyi & 4 & $22,27,28,29$ \\
Bireysel Öğrenme Düzeyi & 4 & $3,15,21,23$ \\
\hline
\end{tabular}

Tablo 8 incelendiğinde ölçekteki maddelerin çoğunun motive ve görsellik düzeyi faktörleri altında toplandığı görülmektedir.

DFA, LISREL ve AMOS programları kullanılarak yapılabilmektedir (Seçer, 2015). Araştırma kapsamında DFA, LISREL programı kullanılarak yapılmıştır. DFA yapılırken modelin uygunluğu için bazı ölçütler dikkate alınmıştır. Yapılan analizler sonucunda elde edilen uyum değerleri ve DFA için en iyi uyum değerleri Tablo 9' da sunulmuştur (aktaran Orhan Göksün, 2016). Ayrıca Derin, Aydın ve Kırkaç tarafından uyum indeksleri şöyle ifade edilmektedir: uyum indeksleri X²/sd (ki-kare / serbestlik derecesi), RMSA (yaklaşık hataların ortalama karekökü), RMR (ortalama hataların karekökü), SRMR (standartlaştırılmış ortalama hataların karekökü), CFI (karşılaştırmalı uyum indeksi), NNFI (normsuz uyum indeksi) olarak açıklanmıştır (Derin, Aydın ve Kırkaç, 2017).

Tablo 9.Tutum ölçeği için DFA sonuçları

\begin{tabular}{lccl}
\hline $\begin{array}{l}\text { Uyum } \\
\text { İndeksi }\end{array}$ & $\begin{array}{c}\text { En İyi Uyum } \\
\text { Değeri }\end{array}$ & $\begin{array}{c}\text { Gözlenen Uyum } \\
\text { Değeri }\end{array}$ & \multicolumn{1}{c}{ Kaynak } \\
\hline$\chi 2 /$ sd & $0 \leq \chi^{2} / \mathrm{sd} \leq 2$ & 2.14 & (Tabachnick ve Fidell, 2012) \\
RMSEA & $0 \leq \mathrm{RMSEA} \leq .05$ & 0.051 & (Schumacker ve Lomax, 2004) \\
SRMR & $0 \leq \mathrm{SRMR} \leq .05$ & 0.061 & (Kenny, 2010) \\
NFI & $.95 \leq \mathrm{NFI} \leq 1$ & 0.94 & (Kenny, 2010) \\
NNFI & $.95 \leq \mathrm{NNFI} \leq 1$ & 0.96 & (Arbuckle, 2007) \\
CFI & $.95 \leq \mathrm{CFI} \leq 1$ & 0.97 & (Hu ve Bentler, 1999) \\
GFI ve AGFI & GFI $>$ AGFI & $0.87>0.85$ & (Bluch, 2008; MacCallum ve Sehee, 1997) \\
\hline
\end{tabular}

Tablo 9 incelendiğinde gözlenen bazı değerler ideal değerler olduğu gibi bazı değerler ideal değerlere yaklaşmışlardır. DFA sonucunda Ki-kare uyum indeksinin $\left(\chi^{2}=1094.96, p=.000, d f=512, \chi^{2} / d f=2.14\right)$ anlamlı olduğu görülmektedir. 


\section{Ölçüt geçerliği}

Bir ölçme aracının geçerliği, yeterli derece güvenilir ve geçerli olarak kabul edilen başka bir ölçme aracıyla korelasyonuna bakılarak karar verilir. Bu şekildeki geçerliği test etmeye ölçüt geçerliği denir (Turgut ve Baykul, 2015). Araştırmamız kapsamında Arslan (2014) tarafından geliştirilen "akıllı tahta kullanımına yönelik tutum ölçeği" kullanılmıştır. Ancak ölçüt geçerliği için geçerliliği ve güvenirliği sağlanmış başka bir ölçek kullanılmamış olup Arslan (2014) tarafından geliştirilen ölçeğe ilişkin veriler ile bu araştırma kapsamında elde edilen veriler kıyaslanmıştır.

- Arslan (2014), öğretmen ve öğrencilerle görüşmeler yaparak 83 maddelik ölçeği uzman görüşleri ve değerlendirmeler sonunda 51 maddeye düşürmüştür. Bu doğrultuda ölçeği Sivas İlinde 440 ortaöğretim öğrencisine uygulamıştır. Gerekli analizlerden sonra ölçek 36 maddeye düşmüştür. Bizim araştırmamızda ise 36 maddelik bu ölçek uzman ve öğretmen görüşleri doğrultusunda fen bilimleri dersine uyarlanmış ve gerekli düzeltmeler yapılmıştır. Bu doğrultuda ölçek Kayseri İlinde 438 öğrenciye uygulanmıştır. Gerekli analizlerden sonra ölçek 34 maddeye düşürülmüştür.

- Arslan (2014), 42 maddeden oluşan taslak ölçeği faktör analizine tabi tutmadan önce Kaiser-Meyer-Olkin (KMO) ölçütü hesaplanmıştır $(K M O=0.940$ ve Bartlett $=6256.03 ; p<0.001)$. Bu araştırmada ise 34 maddelik ölçeğin Kaiser-Meyer-Olkin (KMO) ölçütü hesaplanmıştır $(K M O=0.926$ ve Bartlett=5878.62; $p<0.001)$.

- Arslan (2014), ölçeğin AFA sonucunda altı faktörlü bir yapıda olduğunu bulmuştur. Bu araştırmada ölçeğin altı faktörlü bir yapıda olduğunu bulunmuştur.

- Arslan (2014), ölçeğin alt boyutlarına ait Cronbach $\alpha$ değerlerinin .533 ile .905 arasında değer aldığ olarak hesaplamıştır. Bu araştırmada ise ölçeğin alt boyutlarına ait Cronbach $\alpha$ değerlerinin .631 ile .893 arasında değer aldığı ve ölçeğin toplam Cronbach $\alpha$ değeri ise .920 olarak hesaplanmıştır.

$\mathrm{Bu}$ veriler 1şığında araştırmada kullanılan ölçeğin, Arslan (2014) tarafından geliştirilen ölçeğin bulguları ile benzer sonuçlar verdiği görülmüştür. Bu bağlamda ölçüt geçerliğinin sağlandığı düşünülebilir.

\section{Güvenirliğe ilişkin bulgular}

Tutum ölçeğinde geçerliğe ilişkin yapılan çalışmaların ardından ölçeğin güvenirlik çalı̧̧masına geçilmiştir. Güvenirlik, bireylerin bir ölçekteki maddelere verdikleri cevaplara ilişkin tutarlılık olarak ifade edilmektedir (Büyüköztürk, 2011). Güvenirlik çalışmaları için Cronbach Alfa katsayısına bakılmıştır. Ölçeğe ilişkin güvenirlik sonuçları tablo 10 ' da verilmiştir. 
Tablo 10. Ölçeğe ilişkin güvenirlik sonuçları (Cronbach's Alpha)

\begin{tabular}{lccc}
\hline Faktörler & Cronbach's Alpha & $\begin{array}{c}\text { Standartlaştırılmış Maddelere } \\
\text { Dayalı Alfa Değeri }\end{array}$ & Madde Sayısı \\
\hline Motive Düzeyi & .892 & .893 & 10 \\
Görsellik Düzeyi & .835 & .835 & 7 \\
Bilişsel Düzey & .727 & .729 & 5 \\
Öğrenme Algı Düzeyi & .745 & .744 & 4 \\
Fiziksel Hareket Düzeyi & .650 & .650 & 4 \\
Bireysel Öğrenme Düzeyi & .628 & .631 & 4 \\
\hline Toplam & .919 & .920 & 34 \\
\hline
\end{tabular}

34 maddelik tutum ölçeği için, Cronbach Alfa güvenirlik katsayısı .92 olarak bulunmuştur. Ayrıca ölçeğin alt boyutlarına ait Cronbach $\alpha$ değerlerinin .631 ile .893 arasında değer aldığı tablo 10'de görülmektedir. Cronbach Alfa güvenirlik değeri .70 ve üzerinde hesaplanan ölçeklerin güvenilirliği açısından uygun olduğu kabul edilmektedir (Büyüköztürk, 2011). Bu bağlamda Cronbach Alfa güvenirlik değeri .70 üzerinde olduğu görüldüğünden mevcut ölçeğin güvenilir olduğu sonucuna ulaşılmıştır.

Item-total istatistik sonuçları Tablo 11'de verilmiştir. Bu tablo ile ölçekten hangi madde çıkarılırsa güvenirlik katsayısının ne olacağı verilmiştir.

Tablo 11. Ölçekteki maddeleri güvenirlik katsayısına etkisi

\begin{tabular}{|c|c|c|c|c|}
\hline $\begin{array}{c}\text { Madde } \\
\text { No }\end{array}$ & $\begin{array}{c}\text { Madde } \\
\text { Silindiğinde Test } \\
\text { Ortalaması }\end{array}$ & $\begin{array}{c}\text { Madde } \\
\text { Silindiğinde Test } \\
\text { Varyansı }\end{array}$ & $\begin{array}{c}\text { Düzeltilmiş } \\
\text { Toplam-Madde } \\
\text { Korelasyonu }\end{array}$ & $\begin{array}{c}\text { Madde } \\
\text { Silindiğinde } \\
\text { Cronbach's } \\
\text { Alpha }\end{array}$ \\
\hline 1 & 118.51 & 392.667 & .625 & .915 \\
\hline 2 & 118.72 & 397.737 & .529 & .916 \\
\hline 3 & 119.38 & 406.396 & .306 & .919 \\
\hline 4 & 118.58 & 390.523 & .676 & .914 \\
\hline 5 & 118.90 & 393.875 & .586 & .915 \\
\hline 6 & 119.01 & 403.451 & .354 & .918 \\
\hline 7 & 118.62 & 390.035 & .663 & .914 \\
\hline 8 & 118.82 & 391.869 & .623 & .915 \\
\hline 9 & 118.80 & 390.539 & .668 & .914 \\
\hline 10 & 118.80 & 395.226 & .541 & .916 \\
\hline 11 & 118.88 & 400.180 & .441 & .917 \\
\hline 12 & 119.34 & 400.329 & .367 & .918 \\
\hline 13 & 118.91 & 398.663 & .413 & .918 \\
\hline 14 & 118.68 & 395.783 & .496 & .916 \\
\hline 15 & 119.16 & 397.285 & .469 & .917 \\
\hline 16 & 118.92 & 395.994 & .488 & .916 \\
\hline 17 & 118.45 & 402.463 & .406 & .917 \\
\hline 18 & 118.63 & 397.996 & .495 & .916 \\
\hline 19 & 118.66 & 393.952 & .605 & .915 \\
\hline 20 & 118.87 & 399.372 & .438 & .917 \\
\hline 21 & 119.41 & 405.729 & .279 & .919 \\
\hline 22 & 119.16 & 412.247 & .159 & .921 \\
\hline
\end{tabular}




\begin{tabular}{lllll}
23 & 119.02 & 396.132 & .547 & .916 \\
24 & 118.79 & 393.729 & .594 & .915 \\
25 & 118.87 & 399.828 & .472 & .917 \\
26 & 118.66 & 395.447 & .557 & .916 \\
27 & 119.02 & 402.762 & .373 & .918 \\
28 & 119.15 & 405.767 & .275 & .919 \\
29 & 119.16 & 398.775 & .416 & .917 \\
30 & 118.74 & 395.108 & .527 & .916 \\
31 & 118.64 & 395.783 & .535 & .916 \\
32 & 118.82 & 400.949 & .429 & .917 \\
33 & 118.67 & 394.767 & .554 & .916 \\
34 & 118.93 & 396.497 & .515 & .916 \\
\hline
\end{tabular}

Tablo 11 incelendiğinde, ölçeğin güvenirliği ciddi anlamda etkileyecek bir madde olmadığı sonucuna varılmıştır. Bu bağlamda bütün maddeler ölçeğe dâhil edilecektir. Bu verilere göre araştırmanın veri toplama aracı olan tutum ölçeğinden öğrencilerin aldıkları puanların güvenilir olduğu söylenebilir.

\section{Verilerin Analizi}

Bu bölümde, araştırmada elde edilen verilerin analizine ilişkin bilgilere yer verilmiştir. Uygulama sonucunda elde edilen veriler SPSS istatistik programı kullanılarak analiz edilmiştir. Araştırmada elde edilen veriler 0.05 anlamlılık düzeyinde değerlendirilmiştir.

Fen bilimler dersinde kullanılan akıllı tahtaya yönelik tutum ölçeği, beş dereceli likert tipi bir ölçektir. Ölçekte olumlu ifadeye sahip 23 madde $(1,2,3,4,5,7,8,9,10$, $13,15,19,21,23,24,25,26,30,31,32,33,34,36$. maddeler), olumsuz ifadeye sahip 13 madde $(6,11,12,14,16,17,18,20,22,27,28,29,35$. maddeler) yer almaktadır. Olumsuz ifade içeren maddeler ters kodlanarak veri girişi yapılmıştır. Her bir ifade için "tamamen katılmıyorum", "katılmıyorum", "kararsızım", "katıllyorum", ve "tamamen katılıyorum" şeklinde öğrencilerin düşüncelerini yansıtabilecekleri cevaplar bulunmaktadır. Ateş'e göre ortalama değerler için aralıkları belirlerken beş dereceli likert tipi bir ölçek olduğundan (5-1)/5 formülü kullanılmıştır. Bu hesaplama sonucunda 0.80 değeri elde edilmiştir (Ateş, 2010). Araştırma doğrultusunda hesaplanan ortalama değer aralıkları tablo 12' de verilmiştir.

Tablo 12. Ortalama değer için aralık hesaplama ölçütleri

\begin{tabular}{lcc}
\hline Ö̆ğrenci Görüşleri & Aralık & Düzey \\
\hline Tamamen Katılıyorum & $5.00-4.20$ & Çok Yüksek \\
Katılıyorum & $4.19-3.40$ & Yüksek \\
Kararsızım & $3.39-2.60$ & Orta \\
Katılmıyorum & $2.59-1.80$ & Düşük \\
Tamamen Katılmıyorum & $1.79-1.00$ & Çok Düşük \\
\hline
\end{tabular}

Araştırmada öğrencilerden toplanan ölçek verileri, SPSS analiz programına girilmeden önce herhangi bir karışıklı̆̆a sebebiyet vermemek adına 1'den başlayarak 438 'e kadar numara verilmiştir. Analizler yapılmadan önce ölçek verilerinin SPSS'e 
doğru bir şekilde giriş yapılıp yapılmadığı kontrol edilmiştir. Ayrıca öğrencilerin ölçek verileri, tek tek incelenerek kayıp veri ve tek bir şıkkı işaretleme gibi olumsuz durumların olup olmadığı incelenmiş ve herhangi bir olumsuzluk tespit edilmemiştir. Verilerin analizi "betimsel istatistik" ve "çıkarımsal istatistik" başlıkları altında sunulmuştur.

\section{Betimsel istatistik}

Araştırmamızda betimsel istatistik sonuçları, ölçek verileri üzerinde genel bir fikir sahibi olmak ve analizler yapılmadan önce varsayımların test edilmesinde kullanılmıştır. Araştırmada, Fen bilimler dersinde kullanılan akıllı tahtaya yönelik tutum ölçeği puanlarının normal dağılım varsayımını sağlayıp sağlamadığının tespiti için Kolmogorov-Smirnov, Shapiro-Wilk testi yapılmış ve çarpıklık-basıklık katsayıları, histogramı grafikleri ile ortalama, mod, medyan, standart sapma değerleri incelenmiştir (Pallant, 2016).

Öğrencilerin tutum puanlarının normal dağılım gösterebilmesi için ortalama ve ortanca değerlerinin birbirlerine yakın olması, çarpıklık ve basıklık değerlerinin -1 ve +1 değerleri arasında olması gerekir (Büyüköztürk, 2011). Tutum puanlarının normal dağılım varsayımı gösterip göstermediğini incelemek için kullanılacak başka bir yöntem ise testlerin kullanılmasıdır ki bu testler Kolmogorov-Smirnov ve ShapiroWilk'tir. Örneklem büyüklügünün 50'den az olması durumunda Shapiro-Wilk, 50'den büyük olduğu durumlarda Kolmogorov-Smirnov testi sonuçlarına bakılır (Büyüköztürk, 2011). Analiz sonucunda p değerinin 0.05 'ten büyük olması verilerin normal dağılım gösterdiği şeklinde yorumlanmıştır (Pallant, 2016).

\section{Çıkarımsal istatistik}

Araştırmada hipotezleri test etmek için $t$ testi, Anova analizi yapılmıştır. Araştırma kapsamından $\mathrm{t}$ testi için normallik varsayım kontrol edilmiş, Anova için normallik, varyansların homojenliği varsayım kontrol edilmiştir. Bu varsayımların test edilmesinde aşağıdaki ölçütler dikkate alınmıştır;

Öğrencilerin puanlarının normal dağılım varsayımını karşılayıp karşılamadı ̆̆ hakkında çarpıklık ve basıklık değerlerinden yararlanılır (Tabachnick ve Fidell, 2013). Büyüköztürk (2011), çarpıklık ve basıklık değerlerinin -1 ve +1 değerleri arasında olması halinde normallik varsayımının karşılayacağını ifade etmektedir. Grupların varyanslarının homojenliği için Levene testine bakılmıştır. Varyansların homojenliği varsayımı sig. değerinin 0.05 ten büyük olması $(p>0.05)$ durumunda kabul edilmiştir (Kalaycı, 2017).

Ayrıca bu başlık altında alt problemlerin hangi istatistiksel testlerle analiz edileceğine ilişkin bilgiler verilmiştir. Birinci alt probleminin analizi için bağımsız gruplar t-testi, ikinci alt probleminin analizi için tek yönlü ANOVA ve üçüncü alt probleminin analizi için tek yönlü ANOVA uygulanmıştır. 


\section{Bulgular}

Araştırmanın bu bölümünde, araştırma hipotezlerini test etmek amacıyla betimsel istatistik ardından çıkarımsal istatistik analizi yapılmıştır. Betimsel istatistik başlığı altında, örnekleme ilişkin frekans ve yüzde dağılımları verilmiştir. Ayrıca örneklemin cinsiyet, okul türü ve bilgisayar kullanma tecrübesi ilişkin frekans ve yüzde dağılımları ile uygulanan ölçeğe ilişkin genel bilgiler de verilmiştir. Araştırmanın çıkarımsal istatistik başlığı altında, bağımsız ve bağımlı değişkenlerin arasındaki istatistiksel sonuçlar verilerek araştırma hipotezleri test edilmiştir.

\section{Betimsel İstatistik Bulguları}

Tutum ölçeğinden elde edilen puanların normal dağılım gösterip göstermediğinin belirlenmesi amacıyla betimsel istatistik analizi yapılmıştır. Bunun için tutum puanlarının; ortalama, ortanca ve tepe değerleri, basıklık ve çarpıklık değerleri, histogram grafikleri ve Kolmogorov-Smirnov testi sonuçlarını dikkate alınarak tutum puanların normal dağılım gösterip göstermediğine ilişkin analiz sonuçlarına bakılmıştır. Bu bulgulardan öncelikle tutum puanlarının bağımsız değişkenler açısından betimsel istatistik sonuçları Tablo 13'te verilmiştir.

Tablo 13. Bă̆ımsız değişkenlere ilişkin betimsel istatistik sonuçları

\begin{tabular}{|c|c|c|c|c|c|c|c|c|}
\hline $\begin{array}{c}\text { Bağımsız } \\
\text { Değişkenler }\end{array}$ & $\begin{array}{c}\text { Alt } \\
\text { Kategoriler }\end{array}$ & $\begin{array}{c}\text { Kişi } \\
\text { Sayısı }\end{array}$ & $\begin{array}{c}\text { Ortalama } \\
\text { (Mean) }\end{array}$ & $\begin{array}{c}\text { Ortanca } \\
\text { (Medyan) }\end{array}$ & $\begin{array}{c}\text { Tepe } \\
\text { Değer } \\
\text { (Mod) }\end{array}$ & $\begin{array}{c}\text { Standart } \\
\text { Sapma }\end{array}$ & $\begin{array}{c}\text { Çarpiklık } \\
\text { (Skewness) }\end{array}$ & $\begin{array}{c}\text { Basıklık } \\
\text { (Kurtosis) }\end{array}$ \\
\hline \multirow{2}{*}{ Cinsiyet } & $\mathrm{K}_{1 Z}$ & 220 & 122.63 & 126.00 & 102 & 21.90 & -.427 & -.129 \\
\hline & Erkek & 218 & 122.32 & 123.00 & 127 & 19.09 & -.181 & .440 \\
\hline \multirow{3}{*}{ Okul Türü } & $\mathrm{A}$ & 163 & 121.21 & 123.00 & 109.00 & 21.28 & -.216 & -.467 \\
\hline & B & 178 & 124.34 & 127.50 & 126.00 & 20.59 & -.740 & .921 \\
\hline & C & 97 & 121.19 & 118.00 & 110.00 & 19.00 & .348 & -.629 \\
\hline & $0-2$ yil & 95 & 124.53 & 126.00 & 124.00 & 19.30 & -.289 & -.229 \\
\hline Bilgisayar & 3-4 y1l & 83 & 123.00 & 123.00 & 102.00 & 19.66 & .107 & -.582 \\
\hline Kullanma & $5-6$ y1l & 107 & 121.32 & 126.00 & 129.00 & 20.24 & -.555 & .207 \\
\hline \multirow[t]{2}{*}{ Tecrübesi } & 7-8 y1l & 102 & 120.45 & 122.00 & 127.00 & 22.95 & -.295 & .123 \\
\hline & 9- üzeri y1l & 51 & 124.27 & 126.00 & 117.00 & 19.84 & -.461 & -.368 \\
\hline
\end{tabular}

Tablo 13 incelendiğinde basıklık ve çarpıklık değerinin -1 ve +1 değerleri arasında olduğu ayrıca ortalama ve ortanca değerlerinin de birbirine yakın olduğu görülmektedir. Dolayısıyla sekizinci sınıf öğrencilerin fen bilimleri dersinde akıllı tahta kullanımına yönelik toplam tutum puanlarının normal dağılım gösterdiği anlaşılmaktadır.

Sekizinci sınıf öğrencilerin fen bilimleri dersinde akıllı tahta kullanımına yönelik tutum puanlarının cinsiyet ve bilgisayar kullanma tecrübelerine ilişkin öğrenci sayısı, ortalama ve standart sapma değerleri tablo 14 'te verilmiştir. 
Tablo 14. Cinsiyet ve bilgisayar kullanma tecrübelerine ilişkin betimsel istatistik sonuçlarn

\begin{tabular}{lllcc}
\hline Cinsiyet & Bilg. Kullanım Tecrübe & $\mathrm{N}$ & $\overline{\mathrm{X}}$ & $\mathrm{S}$ \\
\hline \multirow{4}{*}{ Kız } & 0-2 yıl & 43 & 123.14 & 20.39 \\
& 3-4 yıl & 46 & 122.26 & 20.21 \\
& 5-6 yıl & 51 & 122.69 & 21.66 \\
& 7-8 yıl & 51 & 120.86 & 24.72 \\
& 9 ve üzeri yıl & 29 & 125.48 & 22.97 \\
\cline { 2 - 5 } Erkek & 0-2 yıl & 52 & 125.67 & 18.46 \\
& 3-4 yıl & 37 & 123.92 & 19.18 \\
& 5-6 yıl & 56 & 120.07 & 18.96 \\
& 7-8 yıl & 51 & 120.04 & 21.28 \\
& 9 ve üzeri yıl & 22 & 122.68 & 15.12 \\
\hline
\end{tabular}

Tablo 14 incelendiğinde kız öğrenciler içinde en yüksek tutum puanları ortalaması 9 ve üzeri yıl bilgisayar kullanma tecrübeleri sahip olanlarınken $(\bar{X}=125.48)$, kız öğrenciler içinde en yüksek tutum puanları ortalaması 0-2 yıl bilgisayar kullanma tecrübeleri sahip olanlardır $(\bar{X}=125.67)$.

Sekizinci sınıf öğrencilerin fen bilimleri dersinde akıllı tahta kullanımına yönelik cinsiyet değişkenine göre toplam tutum puanlarının öğrenci sayısı, ortalama ve standart sapma değerleri tablo $15^{\prime}$ te verilmiştir.

Tablo 15. Cinsiyete göre tutum puanlarına ilişkin betimsel istatistik sonuçları

\begin{tabular}{cccc}
\hline Cinsiyet & $\mathrm{N}$ & $\overline{\mathrm{X}}$ & $\mathrm{S}$ \\
\hline Kiz & 220 & 122.63 & 21.90 \\
Erkek & 218 & 122.32 & 19.09 \\
\hline
\end{tabular}

Tablo 15 incelendiğinde, 220 kız öğrencinin tutum puanı ortalaması 122.63 iken, 218 erkek öğrencinin tutum puanı ortalaması 122.32'dir. Sekizinci sınıf öğrencilerin fen bilimleri dersinde akıllı tahta kullanımına yönelik tutumlarında kızlar ve erkeklerin puanlarının birbirine yakın olduğu görülmektedir. Sekizinci sınıf öğrencilerin fen bilimleri dersinde akıllı tahta kullanımına yönelik tutum puanlarının cinsiyet ve akıllı tahta kullanma becerilerine (okul türü) ilişkin öğrenci sayısı, ortalama ve standart sapma değerleri tablo 16 ' da verilmiştir.

Tablo 16. Cinsiyet ve akıllı tahta kullanma becerilerine ilişkin betimsel istatistik sonuçları

\begin{tabular}{lcccc}
\hline Cinsiyet & Okul Türü & N & $\overline{\mathrm{X}}$ & $\mathrm{S}$ \\
\hline \multirow{3}{*}{ Kız } & A okulu (3 yıl) & 72 & 124.00 & 22.49 \\
& B okulu (2 yıl) & 110 & 121.64 & 21.99 \\
\multirow{3}{*}{ Erkek } & C okulu (1 yıl) & 38 & 122.92 & 20.93 \\
\cline { 2 - 5 } & A okulu (3 yıl) & 91 & 119.00 & 20.12 \\
& B okulu (2 yıl) & 68 & 128.71 & 17.39 \\
\hline
\end{tabular}

Tablo 16 incelendiğinde, kız öğrenciler içerisinde en yüksek tutum ortalamasının A okulundakiler yani akıllı tahtayı üç yıldır kullananlar olduğu 
$(\bar{X}=124.00)$, erkek öğrenciler içerisinde en yüksek tutum ortalamasının B okulundakiler yani akıllı tahtayı iki yıldır kullananlar olduğu görülmektedir $(\bar{X}=$ 128.71). Araştırmaya ilişkin Kolmogorov-Smirnov ve Shapiro-Wilk sonuçları tablo 17 'de verilmiştir.

Tablo 17. Tutum puanlarına ilişkin Kolmogorov-Smirnov ve Shapiro-Wilk sonuçları

\begin{tabular}{lccccccc}
\hline & & \multicolumn{2}{c}{ Kolmogorov - Smirnov } & \multicolumn{3}{c}{ Shapiro - Wilk } \\
& & İstatistik & Sd & $\mathrm{p}$ & İstatistik & sd & $\mathrm{p}$ \\
\hline \multirow{2}{*}{ Cinsiyet } & $\mathrm{K}$ Iz & .075 & 220 & .004 & .979 & 220 & .002 \\
& Erkek & .041 & 218 & .200 & .994 & 218 & .463 \\
\cline { 2 - 8 } Okul Türüu & A okulu & .061 & 163 & .200 & .986 & 163 & .115 \\
& B okulu & .098 & 178 & .000 & .968 & 178 & .000 \\
& C okulu & .102 & 97 & .015 & .970 & 97 & .026 \\
\cline { 2 - 8 } Bilgisayar & $0-1-2$ yıl & .052 & 95 & .200 & .988 & 95 & .575 \\
Kullanma & $3-4$ yıl & .068 & 83 & .200 & .985 & 83 & .454 \\
Tecrübesi & $5-6$ yll & .096 & 107 & .016 & .973 & 107 & .029 \\
& $7-8$ yıl & .056 & 102 & .200 & .984 & 102 & .241 \\
& 9 ve üzeri yıl & .083 & 51 & .200 & .968 & 51 & .184 \\
\hline
\end{tabular}

Tablo 17 incelendiğinde araştırmadaki örneklemin 438 kişi yani 50'den büyük olması sebebiyle Kolmogorov-Smirnov sonuçları dikkate alınacaktır. Araştırmada cinsiyet açısından kızlarda, okul türü açısından C okulunda, bilgisayar kullanma tecrübesi açısından 5-6 yıl kullananların puanları normallik varsayımını ihlal ettiği görülmektedir $(p<0.05)$.

Araştırma doğrultusunda hesaplanan akıllı tahta kullanımına yönelik tutum puanlarına yönelik ortalama değer aralıkları ve bu aralıklarla ölçekte kaç madde bulunduğu tablo 18'de verilmiştir.

Tablo 18. Tutum ölçeğindeki aralıklara ilişkin madde sayısı

\begin{tabular}{lcc}
\hline Öğrenci Görüşleri & Aralık & Madde Sayısı \\
\hline Tamamen Katılıyorum & $5.00-4.20$ & - \\
Katılıyorum & $4.19-3.40$ & 27 \\
Kararsızım & $3.39-2.60$ & 7 \\
Katılmıyorum & $2.59-1.80$ & - \\
Tamamen Katılmıyorum & $1.79-1.00$ & - \\
\hline
\end{tabular}

Tablo 18'de görüldüğü gibi öğrencilerin fen bilimleri dersinde akıllı tahta kullanımına yönelik tutum ölçeğinde yirmi yedi maddeye 'katılıyorum' cevabını vererek olumlu tutuma sahip olduklarını belirtmişlerdir. Ayrıca yedi maddeye de 'kararsızım' cevabını vermişlerdir.

Öğrencilerin, ölçekteki her maddelere ilişkin verdikleri cevapların ortalaması tablo 19 'da gösterilmiştir.

Tablo 19. Maddelere ilişkin cevapların ortalaması

\begin{tabular}{cccccc}
\hline Madde No & $\begin{array}{c}\text { Ortalana } \\
\text { Değer }\end{array}$ & Madde No & $\begin{array}{c}\text { Ortalana } \\
\text { Değer }\end{array}$ & Madde No & Ortalana Değer \\
\hline 1 & 3.97 & 13 & 3.56 & 25 & 3.60 \\
2 & 3.76 & 14 & 3.79 & 26 & 3.82
\end{tabular}




$\begin{array}{cccccc}3 & 3.10 & 15 & 3.31 & 27 & 3.45 \\ 4 & 3.89 & 16 & 3.55 & 28 & 3.32 \\ 5 & 3.58 & 17 & 4.03 & 29 & 3.32 \\ 6 & 3.46 & 18 & 3.84 & 30 & 3.74 \\ 7 & 3.85 & 19 & 3.82 & 31 & 3.84 \\ 8 & 3.66 & 20 & 3.61 & 32 & 3.66 \\ 9 & 3.67 & 21 & 3.07 & 33 & 3.81 \\ 10 & 3.67 & 22 & 3.32 & 34 & 3.54 \\ 11 & 3.60 & 23 & 3.46 & & \\ 12 & 3.14 & 24 & 3.68 & & \end{array}$

Bütün maddelerin genel puan ortalaması: 3.60

Tablo 19 incelendiğinde, öğrencilerin fen bilimleri dersinde akıllı tahta kullanımına yönelik tutumlarının genel olarak olumlu olduğu, bütün maddelerin ortalamasının da 3.60 yani olumlu tutumlarının yüksek düzeyde olduğu söylenebilir.

a. Cinsiyete İlişkin Histogram Grafikleri

Öğrencilerin tutum ölçeği puanlarının cinsiyetlerine ilişkin histogram grafikleri şekil 2'de verilmiştir.
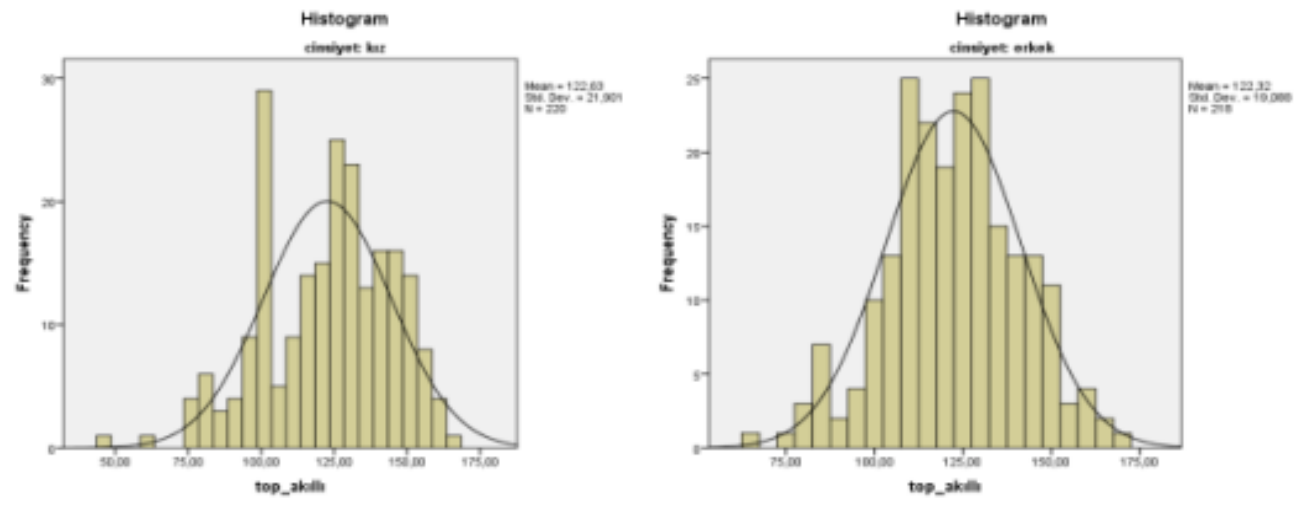

Şekil 2. Tutum ölçeği puanlarının cinsiyete ilişkin histogram grafikleri

Şekil 2’de görüldüğü gibi sekizinci sınıf öğrencilerin fen bilimleri dersinde akıllı tahta kullanımına yönelik cinsiyetlerine göre tutum puanlarının normal dağılım gösterdiği söylenebilir.

\section{b. Okul Türüne İlişkin Histogram Grafikleri}

Öğrencilerin tutum ölçeği puanlarının okul türüne (akıllı tahta kullanımlarına) ilişkin histogram grafikleri şekil 3'te verilmiştir. 

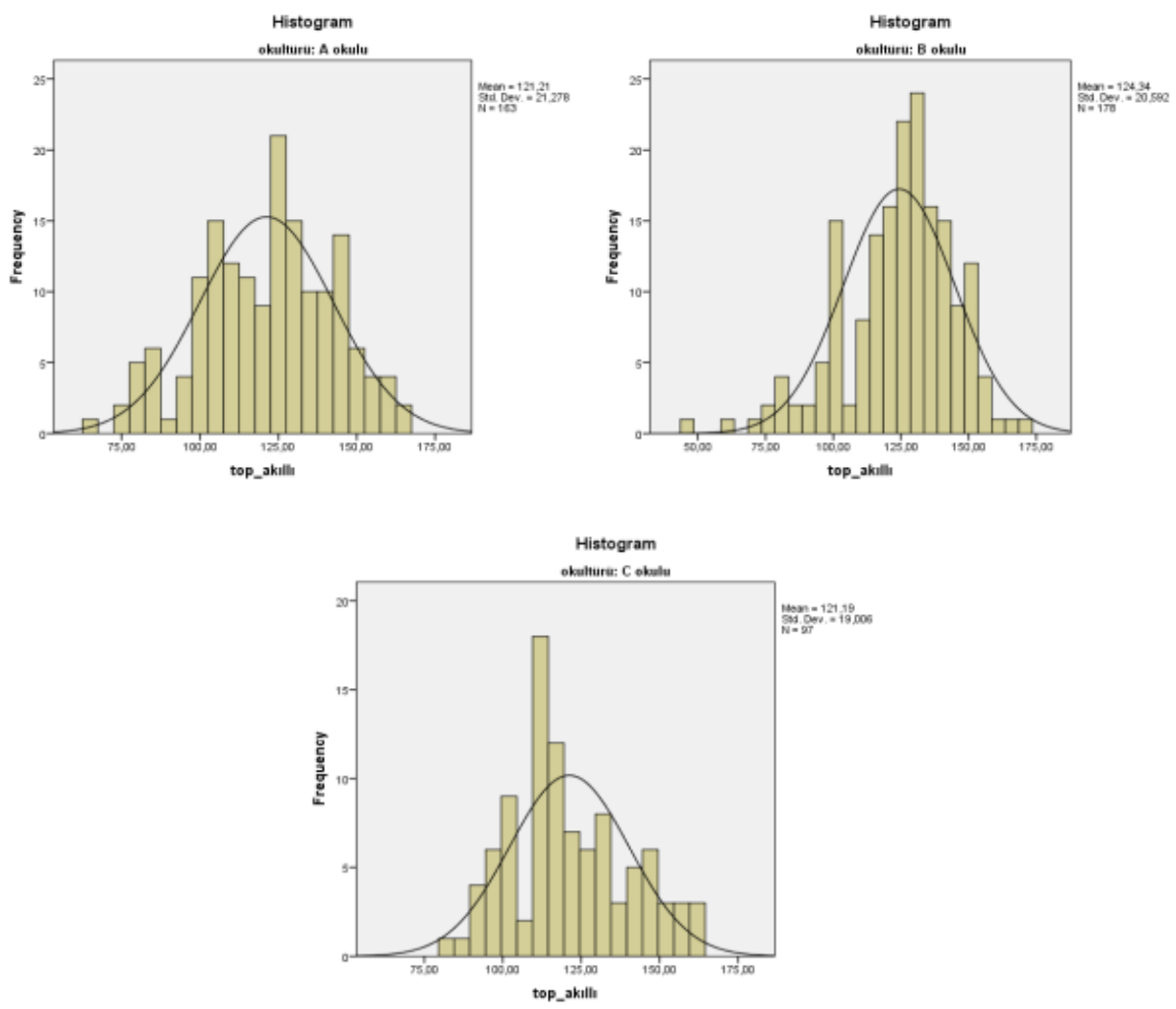

Şekil 3. Tutum ölçeği puanlarının okul türüne ilişkin histogram grafikleri

Şekil 3'te görüldüğü gibi sekizinci sınıf öğrencilerin fen bilimleri dersinde akıllı tahta kullanımına yönelik okul türüne (akıllı tahta kullanımlarına) göre tutum puanlarının normal dağılım gösterdiği söylenebilir.

c. Bilgisayar Kullanım Tecrübesine İlişkin Histogram Grafikleri

Öğrencilerin tutum ölçeği puanlarının bilgisayar kullanma tecrübelerine ilişkin histogram grafikleri şekil 4' te verilmiştir.
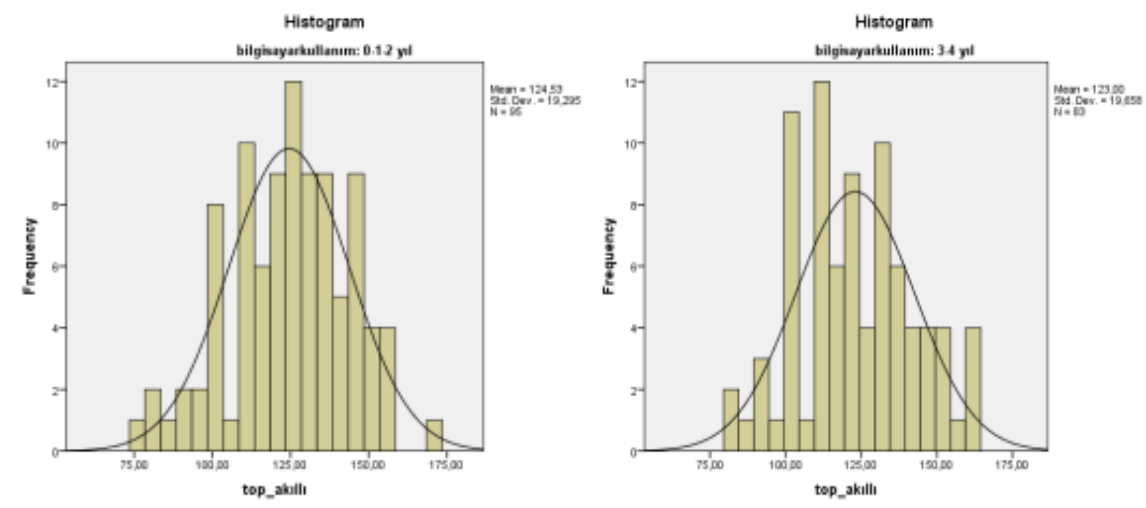

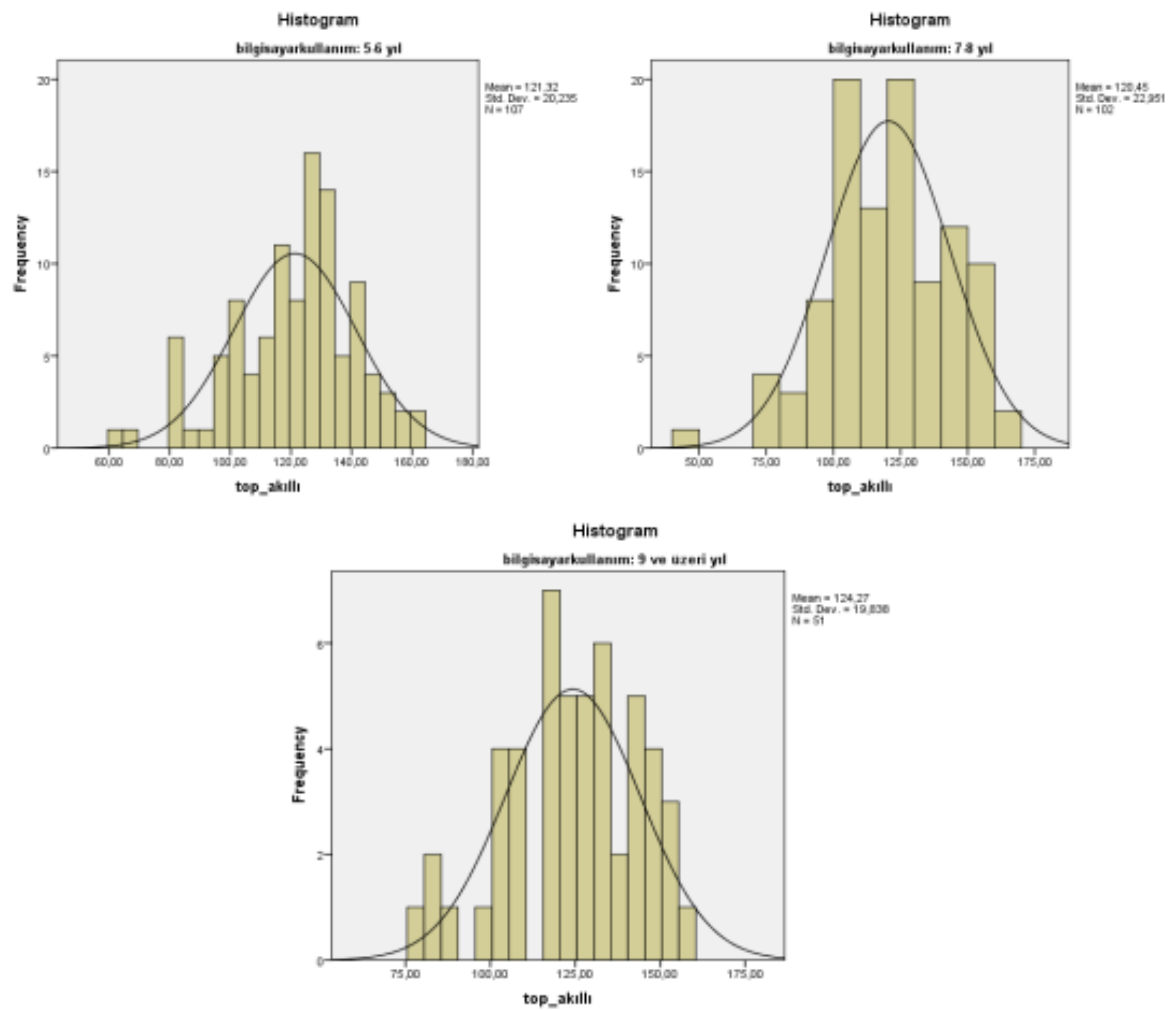

Şekil 4. Tutum ölçeği puanlarının bilgisayar kullanma tecrübelerine ilişkin histogram grafikleri

Şekil 4'te görüldüğ̈ü gibi sekizinci sınıf öğrencilerin fen bilimleri dersinde akıllı tahta kullanımına yönelik bilgisayar kullanma tecrübelerine göre tutum puanlarının normal dağılım gösterdiği söylenebilir. Betimsel istatistik kısmında yapılan analizler sonucunda elde edilen bulgulardan yola çıkarak araştırmaya ilişkin puanların normallik varsayımını karşıladığı söylenebilir. Böylece tekrardan çıkarımsal istatistik bölümünde normallik varsayımı test edilmemiştir. Bu bağlamda araştırmada parametrik olan istatistiksel testler kullanılmıştır.

\section{Çıkarımsal İstatistik Bulguları}

$\mathrm{Bu}$ başlık altında, araştırmanın alt problemleri tek tek ele alınarak hipotezler test edilmiştir.

\section{Cinsiyete göre fen bilimleri dersinde akıllı tahta kullanımına yönelik tutumları}

Sekizinci sınıf öğrencilerinin fen bilimleri dersinde akıllı tahta kullanımına yönelik tutumları, cinsiyete göre anlamlı bir farklılık oluşturup oluşturmadığ tablo 20 'de bağımsız gruplar t-testi ile karşılaştırılmıştır.

Tablo 20. Cinsiyet açısından bağımsız gruplar t-testi ile karşılaştırılması

\begin{tabular}{ccccccc}
\hline Cinsiyet & $\mathrm{N}$ & $\overline{\mathrm{X}}$ & $\mathrm{S}$ & $\mathrm{sd}$ & $\mathrm{t}$ & $\mathrm{p}$ \\
\hline K1z & 220 & 122.63 & 21.90 & 429.02 & 161 & .087 \\
Erkek & 218 & 122.32 & 19.09 & & & \\
\hline
\end{tabular}


Tablo 20 incelendiğinde sekizinci sınıf öğrencilerinin fen bilimleri dersinde akıllı tahta kullanımına yönelik tutumlarının cinsiyetler açısından kızlar ve erkekler arasında istatistiksel olarak anlamlı bir fark olmadığ 1 görülmektedir ( $t=161$, $p=.087>.05)$. Bu sonuca göre $\mathrm{H}_{1}$ kabul edilmiştir.

\section{Yıllara göre akıllı tahta kullanım deneyiminin (1 yıl, 2 yıl, 3 yıl) fen bilimleri dersinde akıllı tahta kullanımına yönelik tutumları}

Analize yürütülmeden önce varyansların homojenliği varsayımını test etmek için Levene's testi sonuçları tablo 21'de verilmiştir.

Tablo 21. Levene's testi varyansların homojenliği sonuçları

\begin{tabular}{cccc}
\hline Levene Statistic & df1 & df2 & Sig. \\
\hline 1.048 & 2 & 435 & .352 \\
\hline
\end{tabular}

Tablo 21 incelendiğinde bağımlı değişken için sig. değerlerinin .05 değerinden yüksek olması varyansların eşitliği varsayımını gösterir. Tablo 21 'te görüldüğü gibi sig. değerinin 0.352 olduğu görülmektedir. Tutum puanlarının varyanslarının eşit olduğunu söylenebilir. Bu durumda 0.05 anlamlılık değerinden büyük olduğundan varyansların homojenliği varsayımı karşılanmıştır $(p>0.05)$.

Sekizinci sınıf öğrencilerinin fen bilimleri dersinde akıllı tahta kullanımına yönelik tutumları, yıllara göre akıllı tahta kullanım deneyiminin (1 yıl, 2 yıl, 3 yıl) tek yönlü ANOVA ile karşılaştırılması tablo 22' de verilmiştir.

Tablo 22.Yıllara göre akıllı tahta kullanım deneyiminin tek yönlü ANOVA ile karşılaştırılması

\begin{tabular}{|c|c|c|c|c|c|}
\hline $\begin{array}{l}\text { Varyansın } \\
\text { Kaynağ1 }\end{array}$ & $\begin{array}{l}\text { Kareler } \\
\text { Toplamı }\end{array}$ & $\mathrm{Sd}$ & $\begin{array}{c}\text { Kareler } \\
\text { Ortalaması }\end{array}$ & F & $\mathrm{p}$ \\
\hline Gruplararası & 1039.88 & 2 & 519.94 & 1.24 & .292 \\
\hline Gruplariçi & 183077.34 & 435 & 420.87 & & \\
\hline Toplam & 184117.22 & 437 & & & \\
\hline
\end{tabular}

Tablo 22 incelendiğinde sekizinci sınıf öğrencilerinin fen bilimleri dersinde akıllı tahta kullanımına yönelik tutumları, yıllara göre akıllı tahta kullanım deneyimi açısından anlamlı bir fark olmadığı görülmektedir $(F(2,435)=1.24, p=.292>.05)$. Bu sonuca göre $\mathrm{H}_{2}$ kabul edilmiştir.

Bilgisayar kullanım tecrübesine (0-2, 3-4, 5-6, 7-8, 9 ve üzeri) göre fen bilimleri dersinde akıllı tahta kullanımına yönelik tutumları

Analize yürütülmeden önce varyansların homojenliği varsayımını test etmek için Levene's testi sonuçları tablo 23 'te verilmiştir.

Tablo 23. Levene's testi varyansların homojenliği sonuçları

\begin{tabular}{cccc}
\hline Levene Statistic & df1 & df2 & Sig. \\
\hline 1.023 & 4 & 433 & .395 \\
\hline
\end{tabular}


Tablo 23 incelendiğinde bağımlı değişken için sig. değerlerinin 0.05 değerinden yüksek olması varyansların eşitliği varsayımını gösterir. Tablo 23’te görüldüğü gibi sig. değerinin 0.395 olduğu görülmektedir. Tutum puanlarının varyanslarının eşit olduğunu söylenebilir. Bu durumda 0.05 anlamlılık değerinden büyük olduğundan varyansların homojenliği varsayımı karşılanmıştır $(p>0.05)$.

Sekizinci sınıf öğrencilerinin fen bilimleri dersinde akıllı tahta kullanımına yönelik tutumları, bilgisayar kullanım tecrübe düzeylerinin (0-2, 3-4, 5-6, 7-8, 9 ve üzeri) tek yönlü ANOVA ile karşılaştırılması tablo 24'te verilmiştir.

Tablo 24. Bilgisayar kullanım tecrübelerinin tek yönlü ANOVA ile karşılaştırılması

\begin{tabular}{lccccc}
\hline Varyansın Kaynağı & $\begin{array}{c}\text { Kareler } \\
\text { Toplamı }\end{array}$ & Sd & $\begin{array}{c}\text { Kareler } \\
\text { Ortalaması }\end{array}$ & F & p \\
\hline Gruplararası & 1148.93 & 4 & 287.23 & .680 & .606 \\
Gruplariçi & 182968.29 & 433 & 422.56 & & \\
Toplam & 1841170224 & 437 & & & \\
\hline
\end{tabular}

Tablo 24 incelendiğinde sekizinci sınıf öğrencilerinin fen bilimleri dersinde akıllı tahta kullanımına yönelik tutumları açısından bilgisayar kullanım tecrübe düzeyleri arasında istatistiksel olarak anlamlı bir fark olmadığı görülmüştür $(F(4,433)=0.680, p=.606>.05)$. Bu sonuca göre $\mathrm{H}_{3}$ kabul edilmiştir.

\section{Sonuç ve Tartışma}

Araştırmada, sekizinci sınıf öğrencilerinin fen bilimleri dersinde kullanılan akıllı tahtaya yönelik tutumları tespit edilerek, bunun cinsiyet, yıllara göre akıllı tahta deneyimi ve bilgisayar kullanım tecrübesi değişkenlerine göre farklılaşma durumlarının ortaya koyulması amaçlanmıştır. Bu başlık altında araştırmaya ilişkin sonuç ve tartışmalara yer verilmiştir.

\section{Genel Tutum Düzeyi}

Türkiye'de son yıllarda eğitim-öğretim faaliyetlerinde kullanılmaya başlanan akıllı tahtaların etkilerinin bilinmesi, öğrenci görüşlerinin elde edilmesi eğitimöğretim faaliyetlerinin verimli olması için önemlidir. Araştırmada, sekizinci sınıf öğrencilerinin fen bilimleri dersinde kullanılan akıllı tahtaya yönelik tutum düzeylerine bakıldığında "katılıyorum $\bar{X}=3.60$ " düzeyinde cevaplandırdıkları sonucuna ulaşılmıştır. Bu sonuçlar eğitim-öğretim faaliyetlerinde akıllı tahta kullanımı ile ilgili daha önce yapılan araştırmalarla tutarlıdır (Akçayır, 2011; Beauchamp ve Kennewell, (2008); Beelend, 2002; Hall ve Higgins'in (2005); Hiçyılmaz, 2015; Hwang, Chen ve Hsu, 2006; Clemens vd. 2011; Oleksiw, 2007; Önder, 2015; Özhan, 2012; Smith vd., 2005; Sünkür vd., 2012; Tekin, 2013; Tercan, 2012; Tiryaki, 2014; Türkoğlu, 2014). Ancak Bağc1 (2013) ve Tataroğlu'nun (2009) 
çalışmalarında, öğrencilerin ölçekten elde edilen toplam puan ortalamalarının akıllı tahtaya yönelik tutumlarının orta düzeyde olduğu görülmektedir.

$\mathrm{Bu}$ genel sonuç çerçevesinde öğrencilerin fen bilimleri dersinde kullanılan akıllı tahtaya yönelik olumlu tutumlara sahip oldukları ve akıllı tahtalardan memnun oldukları söylenebilir. Öğrencilerin aklı tahtaya yönelik olumlu tutum geliştirilmesi İnteraktif tahtaların öğrenciler tarafından eğlenceli ve keyifli bulmasından (Hall ve Higgins, 2005); öğrencilerin geleneksel öğretim yerine akıllı tahta kullanımı veya diğer teknolojik araçların kullanımını tercih etmelerinden (Clemens vd. 2011); derslerde akıllı tahta kullanımının öğrencilerin derse olan ilgilerini artırmasından, öğrencilerin dikkatini çekmesinden, öğrenci başarısını artırmasından (Beelend 2002) kaynaklandığ1 düşünülebilir. Ayrıca derslerde akıllı tahta kullanımı öğrencinin ilgisini, motivasyonunu ve dikkatini artırdığı Beauchamp ve Kennewell, (2008), öğrencilerin akıllı tahta ile kendi deneyimlerinin bulunmasının öğrenci ilgi ve isteklerini artırdığ (Luo ve Yang, 2016) tespit edilmiştir. Bu çalışma bu yönüyle de alanyazınla tutarlıdır.

Bağcı (2013) akıllı tahtaya yönelik tutumlarının orta düzeyde çımasını, öğrencilerin akıllı tahta ile ilk kez karşılaştıkları için bir tanıma sürecinde oldukları ve bu süreçte de akıllı tahtaya olan görüşlerinin de pozitif veya negatif yönde şekillenmediğini belirtmiştir. Tataroğlu (2009) ise öğrencilerin akıllı tahta ile ilk kez karşılaştıkları için bir uyum sorunu yaşadıkları ve uygulama sürecinde akıllı tahta kullanımını yoğun bulmuş olabileceklerini belirterek öğrencilerin bu durumda akıllı tahtaya yönelik olumlu veya olumsuz belirgin fikirlere sahip olmalarını engellemiş olabileceğini belirtmiştir.

Fen bilimleri dersinde kullanılan akıllı tahtaya yönelik olumlu tutumlara sahip oldukları sonucundan yola çıkarak, öğrenciler açısından teknolojiyi kullanmanın eğitim-öğretim faaliyetleri için iyi bir fırsat sağladığı düşünülebilir. Araştırma sonucundan yola çıkarak öğrencilerin akıllı tahta kullanıldığında; dersin daha iyi anlaşıldığı, dersten daha çok keyif aldıkları, dersin daha verimli geçtiği, derse canlılık kattığı, kendilerini rahat ve daha güvenli hissettikleri, kendi hızlarına göre öğrenme gerçekleştiği ortaya çıkmıştır.

\section{Cinsiyet Açısından Tutumlar}

Araştırmada, sekizinci sınıf öğrencilerinin fen bilimleri dersinde akıllı tahta kullanımına yönelik tutumlarının cinsiyetler açısından kızlar ve erkekler arasındaki farkın anlamlı olmadığı sonucuna ulaşılmıştır. Bu sonuç, eğitim-öğretim faaliyetlerinde akıllı tahta kullanımına yönelik tutumlar ile cinsiyet değişkenine ilişkin yapılan araştırma sonuçları tutarlıdır (Bağcl, 2013; Hiçyılmaz, 2015; Özhan, 2012; Tataroğlu, 2009; Türkoğlu, 2014). Akıllı tahta kullanımına yönelik tutumun cinsiyete göre değiştiği araştırmalar da mevcuttur (Aytaç, 2013; Balta ve Duran, 2015; Günbatar ve Gökçearslan, 2015). Aytaç (2013) kız öğrencilerin, Balta ve Duran (2015) ise erkek öğrencilerin daha yüksek düzeyde olumlu tutuma sahip olduğu sonucuna ulaşmıştır. Ayrıca Günbatar ve Gökçearslan (2015), akıllı tahtaya yönelik olumlu, 
olumsuz ve toplam tutumları cinsiyet açısından incelemiştir. Olumlu tutum ve toplam tutumda cinsiyet açısından anlamlı bir farklılık oluşturmazken, olumsuz tutumlarda cinsiyete göre anlamlı bir farklilık bulmuştur. Olumsuz tutum puanlarında erkekler kızlara göre daha yüksek düzeyde olduğu görülmüştür.

Alanyazındaki diğer araştırma sonuçlarından ve bu araştırma sonucundan elde edilen veriler ışığında akıllı tahta kullanımına yönelik tutumların cinsiyet açısından anlamlı bir farklılık oluşturmaması, teknolojik olanaklar konusunda kız ve erkek öğrenciler arasında bir farklılık oluşturmadığı düşünülebilir. Araştırmada öğrencilerin, benzer çevre olanaklarına sahip, aynı sınıf seviyelerinde oldukları göz önüne alındığında cinsiyetin akıllı tahtaya yönelik tutumlarında farklılık oluşturan belirleyici bir değişken olmadı̆̆ı söylenebilir. Ayrıca günümüzde artık öğrencilerin yeni teknolojik ürünlerle çok ilgili olmaları ve bu bağlamda cinsiyet fark etmeksizin benzer bakış açısına sahip oldukları da söylenebilir.

\section{Yıllara Göre Akıllı Tahta Deneyimi Açısından Tutumlar}

Sekizinci sınıf öğrencilerinin fen bilimleri dersinde akıllı tahta kullanımına yönelik tutumları, yıllara göre akıllı tahta kullanım deneyimi açısından farkın anlamlı olmadığı sonucuna ulaşılmıştır. Bu sonuç, Hiçyılmaz (2015) ve Elaziz'in (2008) araştırma sonuçları ile çelişmektedir. Hiçyılmaz (2015), öğrencilerin akıllı tahtaya yönelik tutum ölçeği puanları akıllı tahta kulanım süresi değişkeni arasında anlamlı bir farklılık bulmuştur. Bu farklılık akıllı tahta kullanım süresi üç yıl olan öğrencilerin akıllı tahtaya yönelik tutum puanları, akıllı tahta kullanım süresi iki yıl ve bir y1l olan öğrencilerinkine göre daha yüksek olduğu yönündedir. Elaziz (2008) ise akıllı tahtaya yönelik tutumların kullanım süresine göre anlamlı farklılık oluşturduğu ve bu farklılığın daha sik kullananlar lehine olduğu sonucuna ulaşmıştır. Farklı bir araştırmada ise Özhan (2012), tutum puanlarının akıllı tahta kullanım sıklığına göre anlamlı bir farklılık göstermediği sonucuna ulaşmıştır.

Hiçyılmaz'ın (2015), öğrencilerin akıllı tahtaya yönelik tutum puanları akıllı tahta kulanım süresi değişkeni arasında anlamlı bir farklılık bulmasının sebebi farklı sınıf seviyesindeki lise öğrencileri üzerinde bir araştırma yapmış olmasından kaynaklamış olabilir. Bu anlamlı farkın, sadece tek bir değişkeni sınamak yerine aynı anda hem sınıf seviyesi hem de akıllı tahta kulanım süresini araştırmaya dâhil etmesinden de kaynaklanmış olabilir. Aynı şekilde Elaziz' in (2008) araştırmasındaki anlamlı farklılı̆̆ı sebebi olarak ilköğretim, ortaöğretim ve üniversite olmak üzere farklı öğrenim seviyelerinden oluşan bir örnekleminin bulunmasından kaynaklı olabilir. Yani Hiçyılmaz (2015) ve Elaziz'in (2008) araştırmalarındaki örneklem seviyelerinin farklılığı bu öğrencilerin akıllı tahtaya yönelik tutum puanları akıllı tahta kulanım süresi değişkeni arasında anlamlı bir farklılık oluşturduğu düşünülebilir. 


\section{Bilgisayar Kullanım Tecrübesi Açısından Tutumlar}

Sekizinci sınıf öğrencilerinin fen bilimleri dersinde akıllı tahta kullanımına yönelik tutumları açısından bilgisayar kullanım tecrübeleri arasındaki farkın anlamlı olmadığ1 sonucuna ulaşılmıştır. Bu sonuçlar, eğitim-öğretim faaliyetlerinde akıllı tahta kullanımına yönelik tutumlar ile bilgisayar kullanım tecrübesine ilişkin yapılan araştırma sonuçları tutarlıdır. Bağ öğrencilerin akıllı tahtaya yönelik görüşleri üzerinde anlamlı bir farklılığa sebep olmadığı sonucuna ulaşmıştır. Tataroğlu'nun (2009) araştırmasında ise öğrencilerin akıllı tahtaya yönelik tutumları ile bilgisayara sahip olma durumları arasında farkın anlamlı olmadığ 1 sonucuna ulaşmıştır. Bu durumu Tataroğlu (2009), günümüz öğrencilerinin şahsi bilgisayarları olmasa da teknolojiyi takip ettikleri, ona uzak olmadıkları şeklinde yorumlamıştır. Öğrencilerin, eğitim-öğretim faaliyetlerinde kullanılan akıllı tahtaya yönelik tutumları ile bilgisayar kullanım tecrübeleri arasında anlamlı bir farklılık bulunması, günümüzde öğrencilerin çok küçük yaşlardan itibaren şahsi bilgisayarları olmasa dahi teknolojiden uzak olmadıklarl; bilgisayar, cep telefonu ve tablet gibi birçok teknolojik aletleri çok rahat bir şekilde kullanabildikleri şeklinde yorumlanabilir.

\section{Öneriler}

$\mathrm{Bu}$ başlık altında, yapılan araştırmadan yola çıkarak ileri yapılacak olan araştırmalara ilişkin bazı öneriler bulunmaktadır.

- $\quad B u$ araştırma, sekizinci sınıf öğrencilerinin fen bilimleri dersinde kullanılan akıllı tahtaya yönelik tutumları tespit edilmiştir. Bundan sonra yapılacak araştırmalarda, akıllı tahtaların farklı derslerde kullanımına yönelik tutumları araştırılabilir.

- $\mathrm{Bu}$ araştırmada, bağımsız değişkenler olarak cinsiyet, yıllara göre akıllı tahta deneyimi ve bilgisayar kullanım tecrübesi değişkenlerinin farklılık oluşturup oluşturmadığı araştırılmıştır. Bundan sonra yapılacak araştırmalarda; sınıf seviyeleri (5-6-7-8. sınıf), öğrenim seviyeleri (ilkokul, ortaokul, lise ve üniversite gibi), öğretmenin akıllı tahta kullanma sıklığ1 gibi değişkenlere ilişkin tutum düzeyleri de araştırılabilir.

- $\mathrm{Bu}$ araştırma, il merkezindeki üç devlet okulunda yapılmıştır. Bundan sonra yapılacak araştırmalarda; il, ilçe ve köyden seçilen okullarla çalışmalar yapılabilir. Ayrıca bir devlet okulu ve bir özel okulda da çalışma yapılarak akıllı tahtaya yönelik tutum düzeyleri belirlenebilir.

\section{Etik Beyan}

"Sekizinci Sınıf Öğrencilerinin Fen Bilimleri Dersinde Akıllı Tahta Kullanımına Yönelik Tutumlarının İncelenmesi" başlıklı çalışmanın yazım sürecinde bilimsel, etik ve alıntı kurallarına uyulmuş; toplanan veriler üzerinde herhangi bir tahrifat 
yapılmamış ve bu çalışma herhangi başka bir akademik yayın ortamına değerlendirme için gönderilmemiştir.

\section{Kaynakça}

Akçayır, M. (2011). Akıllı tahta kullanılarak işlenen matematik dersinin sını öğretmenliği birinci sını öğrencilerinin başarı, tutum ve motivasyonlarına etkisi. Yüksek lisans tezi. Gazi Üniversitesi Eğitim Bilimleri Enstitüsü, Ankara.

Akgün, M. \& Koru-Yücekaya, G. (2015). Akıllı tahta kullanımına yönelik öğrenci tutumu ve öğretmen görüşlerinin incelenmesi (Ankara ili örneği). E-Journal of New World Sciences Academy, 10(3), 1-11.

Aktaş, S. (2015). Fen ve teknoloji dersinde akıllı tahta kullanımının öğrencilerin akademik başarısına ve bilgilerin kalıcılığına etkisi. Yüksek lisans tezi. Kastamonu Üniversitesi Fen Bilimleri Enstitüsü, Kastamonu.

Arslan, R. (2014). Ortaöğretim öğrencilerinin akıllı tahta kullanımına yönelik tutum ölçeği geliştirilmesi, güvenirlik ve geçerlik çalışması: Sivas ili uygulaması. Yüksek lisans tezi. Cumhuriyet Üniversitesi Sosyal Bilimler Enstitüsü, Sivas.

Ateş, M. (2010). Ortaöğretim coğrafya derslerinde akıllı tahta kullanımı. Marmara Coğrafya Dergisi, 22, $409-427$.

Atılgan, H. (Ed.) (2017). Eğitimde ölçme ve değerlendirme (10. Baskı). Ankara: Anı Yayıncılık.

Aytaç, T. (2013). Interactive whiteboard factor in education: students' points of view and their problems. educational research and review, 8(20), 1907-1915.

Bağc1, H. (2013). Fatih projesi çerçevesinde ortaöğretim öğrencilerinin etkileşimli tahtaya yönelik görüşlerinin incelenmesi. Yüksek lisans tezi. Okan Üniversitesi Sosyal Bilimler Enstitüsü, İstanbul.

Balta, N. \& Duran, M. (2015). Attitudes of students and teachers towards the use of interactive whiteboards in elementary and secondary school classrooms. TOJET: The Turkish Online Journal of Educational Technology,14(2), 15-21.

Baydaş Ö., Esgice, M., Kalafat, Ö. \& Göktaş, Y. (2011). Etkileşimli Tahtaların Öğretim Süreçlerine Katkıları. Paper presented at $5^{\text {th }}$ International ComputerEInstructional Technologies Symposium. Furat Üniversitesi, Elâzı ̆̆g, Turkey.

Beauchamp, G. \& Kennewell, S. (2008). The influence of ICT on the interactivity ofteaching. Educ Inf Technol, 13, 305-315.

Beeland, W.D. (2002). Student engagement, visual learning and technology: Can interactive whiteboards help? Annual Conference of the Association of Information Technology for Teaching Education, Trinity College, Dublin.

Bell. M. (2002). Why use an Interactive Whiteboard? A baker's dozen reasons! Teachers. Net Gazette, 3(1).

Bulut, İ., \& Koçoğlu, E. (2012). Sosyal bilgiler öğretmenlerinin akıllı tahta kullanımına ilişkin görüşleri (Diyarbakır ili örneği). Dicle Üniversitesi Ziya Gökalp Ĕ̆itim Fakültesi Dergisi, 19, 242-258. 
Büyüköztürk, Ş., Kılıç Çakmak, E., Akgün, Ö.E., Karadeniz, Ş., \& Demirel, F. (2016). Bilimsel araştırma yöntemleri (22. Baskı). Ankara: Pegem Akademi.

Büyüköztürk, Ş. (2011). Sosyal Bilimler için Veri Analizi El Kitabı (15.Baskı), Ankara: Pegem A Yayıncilık

Clemens, A., Moore, T., \& Nelson B. (2001). Math intervention "smart" project student mathematical analysis and reasoning with technology.

Clemens, A., Moore T., \& Nelson B., 2001. Math Intervention "SMART" Project (Student Mathematical Analysis and Reasoning with Technology).

Çelik, S., \& Atak, H. (2012). Etkileşimli tahta tutum ölçeğinin geçerlik ve güvenirlik çalışması. Anadolu Journal of Educational Sciences International, 2(2), 43-56

Damcott, D., Landato, J., \& Marsh, C. (2000). Report on the use of the smart board interactive whiteboard in physical science.

Derin, G., Aydın, E., \& Kırkaç, A. K. (2017). STEM (Fen-Teknoloji-Mühendislik-Matematik) Eğitimi Tutum Ölçeği. El-Cezerî Fen ve Mühendislik Dergisi, 4(3), 547-559.

Dereli, F. (2016). 6. sınıf Dünya ve Evren konu alanına uyarlanmış bilimin doğası kazanımlarının akıllı tahta etkinlikleri ile öğretimi. Yüksek lisans tezi.Mehmet Akif Ersoy Üniversitesi Eğitim Bilimleri Enstitüsü, Burdur.

Dikmen, S. (2015). Akıllı tahtaların ders başarısına etkisi. Yüksek lisans tezi. Fırat Üniversitesi Eğitim Bilimleri Enstitüsü, Elâzığ.

Doğru, M., \& Aydoğdu, M. (2003). Fen bilgisi öğretiminde kullanılan yöntemlerde karşılaşılan sorunlar ile ilgili öğrenci görüşleri. Pamukkale Üniversitesi Ĕ̆itim Fakültesi Dergisi.1(13), 150-158.

Ebel, R. L., \& Frisbie, D. A. (1991). Essentials of educational measurement. Englewood Cliffs, NJ: Prentice Hall.

Elaziz, M.F. (2008). Attitudes of students and teachers towards the use of Interactive whiteboards in EFL classrooms.Master of Arts. Bilkent University Graduate School of Education, Ankara.

Eke, V.E. (2014). Turkish efl students' opinions towards the use of tablet pcs and interactive whiteboards in efl classrooms. Master of arts. Çă̆ University. Mersin.

Emrem, Y. (2014). Astronomi ve Uzay Bilimleri dersi Gökküresi konusunun akıllı tahta ile uygulamalarının öğrencilerin görsel düşüncelerindeki gelişime etkisi. Yüksek lisans tezi. Marmara Üniversitesi Eğitim Bilimleri Enstitüsü, İstanbul.

Erduran A., \& Tataroğlu B. (2009). Eğitimde akıllı tahta kullanımına ilişkin fen ve matematik öğretmen görüşlerinin karşılaştırılması. 9 $9^{\text {th }}$ Internatıonal Educatıonal Technology Conference (IETC2009), 6-8 Mayıs 2009, Ankara (Bildiri Kitab1 14-21).

Ermiş, U.F. (2012). Fen ve teknoloji dersinde etkileşimli tahta kullanımının akademik başarı ve öğrenci motivasyonuna etkisi. Yüksek lisans tezi. Gazi Üniversitesi Eğitim Bilimleri Enstitüsü Sosyal Bilimler Enstitüsü, Ankara.

Fraenkel, J. R., \& Wallen, N. E. (2008). How to design and evaluate research in education (7. Edition). Boston, McGraw-Hill. 
Furat, E. (2009). Performans görevlerinin öğrencilerin fen ve teknoloji dersine ilişkin tutumlarına ve eleştirel düşünme eğilimlerine etkisi. Yüksek lisans tezi. Ankara Üniversitesi Eğitim Bilimleri Enstitüsü, Ankara.

Gagne, R. M., Briggs, L. J., \& Wager, W. W. (1992). Principles of instructional design (4th ed.). Forth Worth, TX: Harcourt Brace Jovanovich College Publishers.

Glover, D., Miller, D. J., \& Averis, D. (2003) The impact of interactive whiteboards on classroom practice: examples drawn from the teaching of mathematics in secondary schools in England. The Mathematics Education into the 21st Century Project: 1(7), 181-185.

Günbatar, M. S., \& Gökçearslan, Ş. (2017). Ortaokul öğrencilerinin etkileşimli tahtaya yönelik tutum ve öğrenme algıları üzerine bir inceleme. Mersin Üniversitesi Ĕ̆itim Fakültesi Dergisi, 13(2): 497-511

Hall, I., \& Higgins, S. (2005) Primary school students' perceptions of interactive whiteboards, School of Education, Communication and Language Sciences, University of Newcastle upon Tyne, Newcastle upon Tyne, UK.

Henson, R. K., \& Roberts, J. K. (2006). Use of exploratory factor analysis in published research common errors and some comment on improved practice. Educational and Psychological Measurement, 66(3), 393-416.

Hiçyılmaz, Y. (2015). Görsel Sanatlar dersinde öğrencilerin akıll tahtaya yönelik tutumları ve öğretmen görüşlerinin incelenmesi. Yüksek lisans tezi. Atatürk Üniversitesi Eğitim Bilimleri Enstitüsü, Erzurum.

Hwang, W., Chen, N., \& Hsu, R. (2006). Development and evaluation of multimedia whiteboard system for improving mathematical problem solving. Computers $\mathcal{E}$ Education, 46,105-121.

İnceoğlu, M. (2004). Tutum Algı İletişim (5. baskı). Ankara: İyi İşler Yayıncılık.

Isman, A., Abanmy, F. A. A., Hussein, H. B., Saadany, A., \& Abdelrahman, M. (2012). Saudi secondary school teachers attitudes' towards using interactive whiteboard in classrooms. The Turkish Online Journal of Educational Technology-TOJET,11(3), 286296.

Kalaycı, Ş. (Ed.) (2017). SPSS uygulamalı çok değişkenli istatistik teknikleri (8. baskı). Ankara: Dinamik Akademi Yayıncılık.

Kaya, G. (2013). Matematik derslerinde akıllı tahta kullanımının öğrencilerin dönüşüm geometrisi üzerindeki başarılarına etkisi. Yüksek lisans tezi. Gazi Üniversitesi Eğitim Bilimleri Enstitüsü, Ankara.

Kaya, H., \&Aydın, F. (2011). Sosyal bilgiler dersindeki coğrafya konularının öğretiminde akıllı tahta uygulamalarına ilişkin öğrenci görüşleri. Journal of World of Turks, 3(1), 179-189.

Kırbağ Zengin, F., Kırılmazkaya, G., \& Keçeci, G. (2011). Akıllı tahta kullanımının ilköğretim öğrencilerinin fen ve teknoloji dersindeki başarı ve tutumuna etkisi, $5^{\text {th }}$ International Computer \& Instructional Technologies Symposium, 22-24 September 2011, Fırat Üniversitesi, Elâzı̆̆g. 
Külçe, C. (2015). İlköğretim ikinci kademe öğrencilerinin fen bilgisi dersine yönelik tutumları. Yüksek lisans tezi. Pamukkale Üniversitesi Fen Bilimleri Enstitüsü, Denizli.

Luo, Y. F., \& Yang, S. C. (2016). Theeffect of theinteractive functions of white boards on elementary students' learning. Journal of Educational Computing Research, 0735633115628032 .

MEB, (2006). Talim Terbiye Kurulu Başkanlığı. İlköğretim fen ve teknoloji dersi (6-8. simflar) öğretim programı, Ankara.

MEB, (2012). Eğitimde fatih projesi başlad1. http://egitek.meb.gov.tr. Eğitek, (7) 4. Erişim: http://yegitek.meb.gov.tr/elektronikdergi/2012/ocak/files/ocak subat.pdf

Min, K., \& Siegel, C. (2011). Integration of smart board technology and effective teaching. $i-$ manager's Journal on School Educational Technology, 7(1), Jun-Aug 2011,

Oleksiw T. (2007). Increasing math test scores with the smart board interactive whiteboard. Erişim:http://downloads01.smarttech.com/media/sitecore/en/pdf/research_library /k-

12/the_effect_of_the_smart_board_interactive_whiteboard_on_raising_state_test_ scores.pdf

Orhan Göksün, D. (2016). Öğretmen adaylarının 21. yy. öğrenen becerileri ve 21. yy. öğreten becerileri arasındaki ilişki. Doktora Tezi. Anadolu Üniversitesi Eğitim Bilimleri Enstitüsü, Eskişehir.

Önder, R. (2015). Biyoloji dersinde akıllı tahta kullanımının öğrencilerin akademik başarılarına, akıllı tahta kullanımına ve derse yönelik tutumlarına etkisi. Yüksek lisans tezi. Dokuz Eylül Üniversitesi Eğitim Bilimleri Enstitüsü, İzmir.

Özçelik, E. (2015). Fizik öğretiminde akıll tahta kullanımının öğrenci başarısına etkisinin araştırılması. Yüksek lisans tezi. Atatürk Üniversitesi Eğitim Bilimleri Enstitüsü, Erzurum.

Özhan, U. (2012). Illköğretim öğrencilerinin öğrenme stilleri ile derslerindeki akıll tahta kullanımına yönelik görüşleri arasındaki ilişkinin incelenmesi. Yüksek lisans tezi.Frrat Üniversitesi Eğitim Bilimleri Enstitüsü, Elazı̆̆.

Öztan, A. C. (2012). Fen ve teknoloji öğretiminde akıllı tahta kullanımının ilköğretim 7. sınıf öğrencilerinin akademik başarılarına etkisi. Yüksek lisans tezi. Necmettin Erbakan Üniversitesi Eğitim Bilimleri Enstitüsü, Konya.

Pallant, J. (2016). SPSS kullanma kılavuzu SPSS ile adım adım veri analizi. (S. Balcı ve B. Ahi, Çeviri). Ankara: Anı Yayıncılık.

Pamuk, S., Çakır, R., Ergun, M. Yılmaz, B., \& Ayas, C. (2013). Öğretmen ve öğrenci bakış açısıyla tablet PC ve etkileşimli tahta kullanımı: FATİH projesi değerlendirmesi. Kuram ve Uygulamada Ĕ̆itim Bilimleri, 13(3), 1815-1822.

Pekdağ, B. (2005). Fen Eğitiminde Bilgi ve İletişim Teknolojileri. Balıkesir Üniversitesi Fen Bilimleri Enstitüsü Dergisi, 7(2), 86-94.

Pituch, K. A., \& Stevens, J. P. (2016). Applied multivariate statistics for the social sciences: Analyses with SAS and IBM's SPSS (6 ${ }^{\text {th }}$ ed.). New York, NY: Routledge. 
Robinson, M.C. (2004). The Impact of the Interactive Electronic Whiteboard on Student Achievement in Middle School Mathematics. Electronic Thesis, Treatises and Dissertation. The Florida State University. USA.

Sakız, G., Özden, B., Aksu, D., \& Şimşek, Ö. (2014). Fen ve teknoloji dersinde akıllı tahta kullanımının öğrenci başarısına ve dersin işlenişine yönelik tutuma etkisi. Atatürk Üniversitesi Sosyal Bilimler Enstitüsü Dergisi, 18(3), 257-274.

Sarıkaya, S. (2015). Akıllı tahta kullanımının ortaöğretimde işlenen canlıların sınıflandırılması konusunun öğrenimi üzerine etkisi. Yüksek lisans tezi. Gazi Üniversitesi Eğitim Bilimleri Enstitüsü, Ankara.

Saruhan, S. (2015). Müzik derslerinde akıllı tahta kullanımına ilişkin öğretmen görüşlerinin incelenmesi. Yüksek lisans tezi. Gazi Üniversitesi Eğitim Bilimleri Enstitüsü, Ankara.

Seçer, İ. (2015). Psikolojik test geliştirme ve uyarlama süreci: SPSS ve LISREL uygulamaları. Ankara: Anı Yayıncilık.

Seyitoğlu, E. (2014). Akıllı tahta kullanılan matematik dersinden yansımalar. Yüksek lisans tezi.Karadeniz Teknik Üniversitesi Eğitim Bilimleri Enstitüsü, Trabzon.

Smith, A. (2000). Interactive whiteboard evaluation. Erişim: http://www.mirandanet.org.uk/casestudies/124

Smith, H. J., Higgins, S., Wall, K., \& Miller, J., (2005). Interactive whiteboards: boon or bandwagon? A critical review of the literature. Journal of Computer Assisted Learning, 21, 91-101.

Solak, M. (2012). Öğretmenlerin akıllı tahta kullanımına karşı tutumlarının teknoloji kabul modeline göre incelenmesi. Yüksek lisans tezi. Sakarya Üniversitesi Eğitim Bilimleri Enstitüsü, Sakarya.

Sünkür, M., Şanlı, Ö., \& Arabacı, İ. B. (2012). Akıllı tahta uygulamaları konusunda ilköğretim II. kademe öğrencilerinin görüşleri (Malatya ili örneği). $5^{\text {th }}$ International Computer $\mathcal{E}$ Instructional Technologies Symposium. Firat University, Elâzı̆̆.

Tabachnick, B. G., \& Fidell, L. S. (2013). Using Multivariate Statistics (6 ${ }^{\text {th }}$ Ed.). Boston: Pearson.

Tataroğlu, B. (2009). Matematik öğretiminde akıllı tahta kullanımının 10. sını öğrencilerinin akademik başarıları, matematik dersine karşı tutumları ve öz-yeterlik düzeylerine etkileri. Yüksek lisans tezi. Dokuz Eylül Üniversitesi Eğitim Bilimleri Enstitüsü, İzmir.

Tekin, Y. (2013). Fizik eğitiminde akıllı tahta kullanımının öğrencilerin fizik başarılarına ve fiziğe karşı tutumlarına etkisinin incelenmesi. Yüksek lisans tezi. Yüzüncü Yıl Üniversitesi Eğitim Bilimleri Enstitüsü, Van.

Tekinarslan, E., Top, E., Gürer, M. D., Yıkmış, A., Karabulut, A., \& Savaş, Ö. (2015). Etkileşimli tahtada çoklu ortam nesneleriyle yapılan öğretimin öğretmen adaylarının zenginleştirilmiş içerikle öğretime yönelik tutumlarına etkisi. Eğitim Teknolojisi Kuram ve Uygulama, 5(2), 22-38.

Tercan, İ. (2012). Akıllı tahta kullanımının öğrencilerin fen ve teknoloji dersi başarı, tutum ve motivasyonuna etkisi. Yüksek lisans tezi. Necmettin Erbakan Üniversitesi Eğitim Bilimleri Enstitüsü, Konya 
Tiryaki, A. (2014). 6. sınıf kuvvet ve hareket ünitesinde akıll tahta kullanımının öğrenci başarısına ve tutumuna etkisi. Yüksek lisans tezi. İstanbul Üniversitesi Eğitim Bilimleri Enstitüsü, İstanbul.

Turgut, M. F., \& Baykul, Y. (2015). Eğitimde ölçme ve değerlendirme (7. Baskl). Ankara: Pegem A Yayıncilik.

Toscu, S. (2013). The impact of interactive whiteboards on classroom interaction in tertiary level english as a foreiign language classes. Master's thesis. Bilkent University. Ankara.

Türel, Y. K., \& Johnson, T. E. (2012). Teachers' belief and use of interactive whiteboards for teaching and learning. Educational Technology \& Society. 15(1). 381-394.

Türkoğlu, T. (2014). Fen ve teknoloji öğretiminde akıllı tahta kullanımının 6. sinıf öğrencilerinin akademik başarl, tutum ve görüşleri üzerine etkileri. Yüksek lisans tezi. Celal Bayar Üniversitesi Fen Bilimleri Enstitüsü, Manisa.

Yalçınkaya, Y. (2013). Ortaöğretim öğretmenlerinin etkileşimli tahta kullanımına yönelik öz yeterlikleri. Yüksek lisans tezi. Süleyman Demirel Üniversitesi Fen Bilimleri Enstitüsü, Isparta.

Yiğit, N., Bütüner, S. Ö., \& Dertlioğlu, K. (2008). Öğretim amaçlı örütbağ sitesi değerlendirme ölçeği geliştirme. Necatibey Eğitim Fakültesi Elektronik Fen ve Matematik Eğitimi Dergisi, 2(2), 38-51.

Yorgancı, S., \& Terzioğlu, Ö. (2013). Matematik öğretiminde akıllı tahta kullanımının başarıya ve matematiğe karşı tutuma etkisi. Kastamonu Eğitim Dergisi, 21(3), 919930.

Ünal, K. (2015). Ortaöğretim kurumlarında tarih öğretiminde akıllı tahta kullanımına yönelik öğrenci görüşleri. Yüksek lisans tezi. Gazi Üniversitesi Eğitim Bilimleri Enstitüsü, Ankara.

Wall, K., Higgins, S., \& Smith, H. (2005) “The visual helps me understand the complicated things": pupil views of teaching and learning with interactive whiteboards. British Journal of Educational Technology 36(5), 851-867.

Weimer, M. J. (2001). The influence of technology such as SMART board interactive whiteboard on student motivation in the classroom. http://downloads01.smarttech.com/media/sitecore/en/pdf/research_library/k12/the_influence_of_technology_such_as_a_smart_board_interactive_whiteboard _on_student_motivation_in_the_classroom.pdf

Winkler, R. L. (2011). Investigating the Impact of Interactive Whiteboard Professional Development on Lesson Planning and Student Achievement. Doctor of Education Thesis, Liberty University, USA. 